[American Journal of Science, Vol. 305, June, SePtember, October, 2005, P. 826-853]

\title{
A UNIVERSAL SURFACE COMPLEXATION FRAMEWORK FOR MODELING PROTON BINDING ONTO BACTERIAL SURFACES IN GEOLOGIC SETTINGS
}

\author{
DAVID BORROK*, BENJAMIN F. TURNER, and JEREMY B. FEIN
}

Department of Civil Engineering and Geological Sciences, University of Notre Dame, 156 Fitzpatrick Hall, Notre Dame, Indiana 46556

\begin{abstract}
Adsorption onto bacterial cell walls can significantly affect the speciation and mobility of aqueous metal cations in many geologic settings. However, a unified thermodynamic framework for describing bacterial adsorption reactions does not exist. This problem originates from the numerous approaches that have been chosen for modeling bacterial surface protonation reactions. In this study, we compile all currently available potentiometric titration datasets for individual bacterial species, bacterial consortia, and bacterial cell wall components. Using a consistent, four discrete site, non-electrostatic surface complexation model, we determine total functional group site densities for all suitable datasets, and present an averaged set of 'universal' thermodynamic proton binding and site density parameters for modeling bacterial adsorption reactions in geologic systems.

Modeling results demonstrate that the total concentrations of proton-active functional group sites for the 36 bacterial species and consortia tested are remarkably similar, averaging $3.2 \pm 1.0(1 \sigma) \times 10^{-4}$ moles/wet gram. Examination of the uncertainties involved in the development of proton-binding modeling parameters suggests that ignoring factors such as bacterial species, ionic strength, temperature, and growth conditions introduces relatively small error compared to the unavoidable uncertainty associated with the determination of cell abundances in realistic geologic systems. Hence, we propose that reasonable estimates of the extent of bacterial cell wall deprotonation can be made using averaged thermodynamic modeling parameters from all of the experiments that are considered in this study, regardless of bacterial species used, ionic strength, temperature, or growth condition of the experiment. The average site densities for the four discrete sites are $1.1 \pm 0.7 \times 10^{-4}, 9.1 \pm 3.8 \times 10^{-5}$, $5.3 \pm 2.1 \times 10^{-5}$, and $6.6 \pm 3.0 \times 10^{-5}$ moles/wet gram bacteria for the sites with $\mathrm{pK}_{\mathrm{a}}$ values of $3.1,4.7,6.6$, and 9.0, respectively. It is our hope that this thermodynamic framework for modeling bacteria-proton binding reactions will also provide the basis for the development of an internally consistent set of bacteria-metal binding constants. 'Universal' constants for bacteria-metal binding reactions can then be used in conjunction with equilibrium constants for other important metal adsorption and complexation reactions to calculate the overall distribution of metals in realistic geologic systems.
\end{abstract}

\section{INTRODUCTION}

Bacterial cell walls contain a range of organic acid functional groups that can adsorb metal cations and protons from solution, thereby affecting the bioavailability, fate, and transport of trace and contaminant metals in near-surface geologic settings (Tornabene and Edwards, 1972; Warren and Ferris, 1998; Tortell and others, 1999). Functional groups on bacterial surfaces are similar to those found on mineral surfaces in that they are proton active. However, unlike functional groups on mineral surfaces that become doubly protonated and positively charged at low $\mathrm{pH}$, bacterial surface functional groups behave like monoprotic organic acids. Most bacterial surface groups are either protonated and neutrally charged or deprotonated and negatively charged, although amine groups are positively charged when protonated. Aqueous metal

*Present address of corresponding author: U.S. Geological Survey, MS964 Denver Federal Center, Denver, Colorado 80225; dborrok@usgs.gov 
cations interact both electrostatically and covalently with deprotonated functional groups to form bacterial surface complexes. The protonation state of the individual functional groups and the stability of each bacterial surface complex can be described using equilibrium thermodynamics (for example, Fein and others, 1997).

Because of the ubiquity of bacteria in near-surface aqueous systems, thermodynamic models capable of describing bacteria-metal adsorption reactions must be coupled with existing speciation models to establish the overall distribution of metals in real systems. Despite the fact that many bacterial species appear to have similar adsorption characteristics (Daughney and others, 1998; Small and others, 1999; Yee and Fein, 2001; Kulczycki and others, 2002; Ngwenya and others, 2003; Yee and Fein, 2003; Borrok and others, 2004a), development of a 'universal' set of thermodynamic modeling parameters for bacterial surfaces is problematic. It is impossible to compare measured values for stability constants for bacterial surface complexes from different studies or to combine them into a unified thermodynamic model because a consistent modeling framework for describing these reactions does not exist. The problem originates with differences in approaches for modeling bacterial surface protonation reactions, and becomes amplified when the chosen proton adsorption constants and functional group site densities are used to constrain bacteria-metal adsorption stability constants.

Protonation reactions on bacterial surfaces are characterized through modeling of potentiometric titration data. Although acid-base titrations provide rigorous constraints on the overall buffering capacity of the bacterial surface, they cannot be used in isolation to determine the exact mechanisms or reactions responsible for the buffering behavior. Hence, the same potentiometric titration data can be described equally well using a variety of different models, ranging from those which invoke a relatively high number of sites with discrete acidity constants to those that invoke a lesser number of sites that have a Gaussian distribution of acidity constants about a mean site value (Fein and others, 2005). For example, Plette and others (1995) utilize a 3-site Langmuir-Freundlich modeling approach to describe the buffering behavior of Rhodococcus erythropolis A177 bacterial cell walls over the $\mathrm{pH}$ range of 3 to 10, while Cox and others (1999) use a 5-site linear programming model to describe the buffering behavior of Bacillus subtilis over the smaller $\mathrm{pH}$ range of 4 to 10 .

Because it is the proton binding framework that determines the activity of deprotonated functional group sites at a given $\mathrm{pH}$, the chosen proton-binding framework also controls the calculated values of the stability constants for bacteria-metal surface complexes. Because proton-binding models vary widely among individual studies, it is not possible to directly compare acidity constants, functional group site densities or metal adsorption constants in a meaningful way. Hence, before a consistent comparison of thermodynamic metal stability constants can be achieved, a consistent thermodynamic foundation for characterization of bacterial surface protonation reactions must be established.

Chemical (Beveridge and Murray, 1980; Beveridge and Fyfe, 1985) and spectroscopic (Hennig and others, 2001; Boyanov and others, 2002; Kelly and others, 2002; Panak and others, 2002; Jiang and others, 2004) evidence suggests that carboxyl, phosphoryl, hydroxyl, and amine moieties are the dominant proton-active functional groups on most bacterial surfaces. This evidence provides the only real constraint on proton-binding models in that these models must account for binding onto a variety of chemically distinct functional group sites, while at the same time accounting for the magnitude and distribution of the observed buffering behavior from titration experiments. Ionic strength effects, metabolic effects, and the effects of structural damage under acidic and basic $\mathrm{pH}$ conditions add to the confusion of how to best model titration datasets. For example, several studies have suggested that bacterial surface 
electric double-layer interactions play an important role in proton-binding (Plette and others, 1995; van der Wal and others, 1997; Daughney and Fein, 1998; Martinez and others, 2002), and a number of different surface electric field models have been used to account for these effects. A number of studies have used a constant capacitance approach, relating surface charge to surface potential using an arbitrarily assigned capacitance value (Fein and others, 1997; Yee and Fein, 2001; Ngwenya and others, 2003; Haas, 2004). The Donnan electrostatic model, which has also been used by a number of workers (for example, Plette and others, 1995; Martinez and others, 2002; Yee and others, 2004), invokes the assumption that all counter ions necessary to balance the bacterial surface charge are present within the hydrated bacterial cell wall volume (Marinsky and Ephraim, 1986), and this 'Donnan volume' can be estimated, directly measured, or empirically-derived. In contrast to these approaches, Borrok and Fein (2005) use a non-electrostatic modeling approach to demonstrate that the ionic strength effect on bacterial surface proton binding reactions (over the range of $0.01 \mathrm{M}$ to $0.5 \mathrm{M}$ ) is often relatively small and not significantly greater than experimental and modeling uncertainties. Hence, many electrostatic corrections that rely on curvefitting procedures with no external verification of capacitance or Donnan values may not be justifiable.

Claessens and others (2004) demonstrate that after an initial rapid equilibration step, the Gram-negative bacterial species Shewanella putrefaciens continues to actively neutralize base even after 5 hours, presumably through metabolic processes. This suggests that for at least some bacterial species, the equilibration time chosen for a titration is critical to the interpretation of titration results. Borrok and others (2004b) show that exposure to acidic solutions can irreversibly damage bacteria by displacing structurally bound $\mathrm{Mg}$ and $\mathrm{Ca}$, resulting in a net increase in reactive sites. Therefore, bacterial titrations that are conducted to $\mathrm{pH}$ values below approximately 3.5 may overestimate buffering capacity. Clearly, this is a difficult problem to overcome, because it is necessary to characterize proton-binding reactions over the entire $\mathrm{pH}$ range in which they are active, and most bacterial species still have buffering capacity to $\mathrm{pH}$ values well below 3.5. Despite these difficulties, total site densities reported for most bacterial species are similar, suggesting that it may be possible to develop a set of 'universal' thermodynamic modeling parameters to describe proton binding onto bacterial surfaces in geologic systems.

In this study, we compile all currently available potentiometric titration datasets for individual bacterial species, bacterial consortia, and bacterial cell wall components. We use a simplified, discrete site, non-electrostatic surface complexation model to determine proton binding stability constants and total functional group site densities for all suitable datasets. Using this approach, we explore differences in proton binding behavior exhibited by different bacterial species and by the same bacterial species under different experimental conditions. Based on these comparisons, we present an averaged set of 'universal' thermodynamic proton binding constants and associated site densities for modeling bacterial adsorption reactions in geologic systems.

COMPILATION OF PROTON BINDING DATASETS

The proton binding datasets compiled in this study were either provided in electronic format by the original authors, or were digitized from published sources. This compilation is similar in scope to that developed by Milne and others (2001) for proton binding onto dissolved humic substances. In all, 225 individual datasets, representing more than 9000 individual measurements of more than 35 individual bacterial species and bacterial consortia are included in this compilation. With the exception of a few published datasets that did not contain enough information for calculation of necessary parameters, no available data were deliberately excluded. Datasets are labeled numerically and can be found in spreadsheet format at 'http:// 
protofit.sourceforge.net/database'. Datasets with the prefix 'IB' refer to individual bacterial species; datasets with the prefix ' $\mathrm{BC}$ ' refer to bacterial consortia; and datasets with the prefix 'BW' refer to bacterial cell wall components.

The format of reported titration measurements varies considerably among studies. Hence, it was necessary for us to convert some datasets into a standard format, using the following charge balance equation:

$$
\left[\mathrm{C}_{\mathrm{a}}-\mathrm{C}_{\mathrm{b}}\right]=[-\mathrm{Q}]+\left[\mathrm{H}^{+}\right]-\left[\mathrm{OH}^{-}\right]
$$

where $\left[\mathrm{C}_{\mathrm{a}}-\mathrm{C}_{\mathrm{b}}\right]$ is the concentration of acid added minus the concentration of base added; $\left[\mathrm{H}^{+}\right]$and $\left[\mathrm{OH}^{-}\right]$are the concentrations of protons and hydroxyl ions, respectively; and $[-Q]$ is the negative of the 'change in surface charge' from the beginning of the titration or 'net protons added'. Both $\mathrm{pH}$ and [-Q] (typically normalized per gram of biomass) are presented as serial data for each of the compiled titration datasets. Where possible, the concentration and volume of acid or base added $(\mathrm{ml})$ has also been included for additional ease of use. The header for each dataset lists the initial volume of suspension prior to titration, the mass of biomass suspended, the normality of acid or base used in the titration, and the ionic strength of each experiment. Dilution effects (from adding acid and base) have been accounted for in most of the datasets; however, in some cases dilution effects could only be estimated or could not be included based on available data. Generally, the volume of acid or base added was less than 3 percent of the total volume of each suspension. The wet or dry mass of the biomass recorded in the database was taken directly from each published source. However, for modeling purposes in this study, the mass of each suspension was normalized to a wet mass based on the dry mass conversion of 8 wet $\mathrm{g}=1 \mathrm{dry} \mathrm{g}$, which is the average of several previously published values (Fein and Delea, 1999; Daughney and others, 2001; Borrok and others, 2004a). The uncertainties associated with this mass conversion are addressed in a later section. Because of the greater uncertainty involved in converting cell density, in terms of numbers of cells per unit volume, to cell mass, studies that listed only cells per unit volume and did not include an individually calibrated conversion factor (to a mass value) were not included in the modeling portion of this study. The source of each dataset included in the database with a brief description of the data are presented in table 1.

\section{MODELING APPROACH}

The surface complexation modeling approach explicitly accounts for protonation reactions on the bacterial surface, using titration data to solve for stability constants and the number and concentrations of individual functional group sites (for example, Fein and others, 1997). We represent functional groups present on the bacterial surface as a number of discrete monoprotic acids, each of which undergoes the following deprotonation reaction:

$$
\mathrm{R}-\mathrm{A}_{\mathrm{i}} \mathrm{H}^{\circ} \Leftrightarrow \mathrm{R}-\mathrm{A}_{\mathrm{i}}^{-}+\mathrm{H}^{+}
$$

where $\mathrm{R}$ is the bacterium to which the functional group type, $\mathrm{A}$, is attached. The acidity constant, $\mathrm{K}_{\mathrm{a}}$, for reaction (2) can be expressed as:

$$
\mathrm{K}_{\mathrm{a}}=\frac{\left[\mathrm{R}-\mathrm{A}_{\mathrm{i}}^{-}\right] \mathrm{a}_{\mathrm{H}^{+}}}{\left[\mathrm{R}-\mathrm{A}_{\mathrm{i}} \mathrm{H}^{\circ}\right]}
$$

where $\left[\mathrm{R}-\mathrm{A}_{\mathrm{i}}^{-}\right]$and $\left[\mathrm{R}-\mathrm{A}_{\mathrm{i}} \mathrm{H}^{\circ}\right]$ represent the concentration of deprotonated and protonated sites, respectively, and $\mathrm{a}_{\mathrm{H}^{+}}$, represents the activity of protons in the bulk solution.

Over the $\mathrm{pH}$ range of interest in most natural systems (approximately 3 to 9.5 ), previous studies have shown that 4 discrete sites are necessary to provide the best fit for 
TABLE 1

Titration datasets included in compilation (database available at http://protofit.sourceforge.net/database)

\begin{tabular}{|c|c|c|c|c|c|}
\hline $\begin{array}{c}\text { Reference List } \\
\text { (by date published) }\end{array}$ & Label & Bacteria Species & $\begin{array}{l}\text { Ionic Strength } \\
\text { (M) }\end{array}$ & pH Range & $\begin{array}{c}\text { Data } \\
\text { acquisition }\end{array}$ \\
\hline Ams, Ph.D. thesis & $\begin{array}{l}\text { IB41A- } \\
\text { IB41C }\end{array}$ & Shewanella oneidensis & 0.1 & $4-9.5$ & $\begin{array}{l}\text { electronic } \\
\text { format }\end{array}$ \\
\hline $\begin{array}{l}\text { Borrok and } \\
\text { others, 2004a }\end{array}$ & $\begin{array}{l}\text { BC1A- } \\
\text { BC5C }\end{array}$ & $\begin{array}{l}\text { consortia from } \\
\text { uncontaminated settings }\end{array}$ & 0.1 & $2.7-9.6$ & $\begin{array}{l}\text { electronic } \\
\text { format }\end{array}$ \\
\hline $\begin{array}{l}\text { Borrok and } \\
\text { others, 2004c }\end{array}$ & $\begin{array}{l}\mathrm{BC} 6 \mathrm{~A}- \\
\mathrm{BC} 16 \mathrm{C}\end{array}$ & $\begin{array}{l}\text { consortia from contaminated } \\
\text { settings }\end{array}$ & 0.1 & $2.7-9.6$ & $\begin{array}{l}\text { electronic } \\
\text { format }\end{array}$ \\
\hline $\begin{array}{l}\text { Borrok and } \\
\text { others, } 2005\end{array}$ & $\begin{array}{l}\text { IB14A- } \\
\text { IB15C }\end{array}$ & Escherichia coli $K-12$ & $0.003,0.1$ & $2.7-9.6$ & $\begin{array}{l}\text { electronic } \\
\text { format }\end{array}$ \\
\hline $\begin{array}{l}\text { Borrok and Fein, } \\
2005\end{array}$ & $\begin{array}{l}\text { IB1A- } \\
\text { IB6C }\end{array}$ & $\begin{array}{l}\text { Pseudomonas putida and } \\
\text { Pseudomonas mendocina }\end{array}$ & $0.01,0.1,0.5$ & $2.7-9.6$ & $\begin{array}{l}\text { electronic } \\
\text { format }\end{array}$ \\
\hline $\begin{array}{l}\text { Borrok } \\
\text { (unpublished } \\
\text { data) }\end{array}$ & $\begin{array}{l}\text { IB24A- } \\
\text { IB24C }\end{array}$ & Micrococcus ludeus & 0.1 & $2.5-9.5$ & $\begin{array}{l}\text { electronic } \\
\text { format }\end{array}$ \\
\hline $\begin{array}{l}\text { Fein and others, } \\
2005\end{array}$ & $\begin{array}{l}\text { IB7A- } \\
\text { IB9B }\end{array}$ & Bacillus subtilis & $0.01,0.1,0.3$ & $3-9$ & $\begin{array}{l}\text { electronic } \\
\text { format }\end{array}$ \\
\hline $\begin{array}{l}\text { Claessens and } \\
\text { others, } 2004 \\
\end{array}$ & $\begin{array}{l}\text { IB30A- } \\
\text { IB30D }\end{array}$ & Shewanella putrefaciens & 0.01 & $3.5-10$ & $\begin{array}{l}\text { electronic } \\
\text { format }\end{array}$ \\
\hline Haas, 2004 & $\begin{array}{l}\text { IB42A- } \\
\text { IB51 }\end{array}$ & $\begin{array}{l}\text { Shewanella putrefaciens } \\
\text { (species 200R, B31, U14) }\end{array}$ & 0.1 & $4-9.5$ & $\begin{array}{l}\text { electronic } \\
\text { format }\end{array}$ \\
\hline $\begin{array}{l}\text { Ngwenya and } \\
\text { others, } 2003\end{array}$ & IB-36 & Genus Enterobacteriaceae & 0.01 & $3-11$ & digitized \\
\hline $\begin{array}{l}\text { Martinez and } \\
\text { others, } 2002\end{array}$ & $\begin{array}{l}\text { IB16A- } \\
\text { IB23D }\end{array}$ & $\begin{array}{l}\text { Escherichia coli and Bacillus } \\
\text { subtilis }\end{array}$ & $\begin{array}{l}0.01,0.05 \\
0.1,0.5 \\
\end{array}$ & $3-10$ & $\begin{array}{l}\text { electronic } \\
\text { format }\end{array}$ \\
\hline $\begin{array}{l}\text { Phoenix and } \\
\text { others, } 2002\end{array}$ & $\begin{array}{l}\text { IB57A- } \\
\text { IB57C }\end{array}$ & $\begin{array}{l}\text { Cyanobacterium Calothrix sp. } \\
\text { Strain KC } 97\end{array}$ & 0.01 & $4-10$ & $\begin{array}{l}\text { electronic } \\
\text { format }\end{array}$ \\
\hline $\begin{array}{l}\text { Daughney and } \\
\text { others, } 2001\end{array}$ & $\begin{array}{l}\text { IB54A- } \\
\text { IB56C }\end{array}$ & Bacillus subtilis & 0.01 & $4-10$ & digitized \\
\hline $\begin{array}{l}\text { Esposito and } \\
\text { others, } 2001\end{array}$ & IB25 & Sphaerotilus natans & Unknown & $3-10$ & digitized \\
\hline $\begin{array}{l}\text { Haas and others, } \\
2001\end{array}$ & $\begin{array}{l}\text { IB33A- } \\
\text { IB33C }\end{array}$ & Shewanella putrefaciens & $0.1,0.05$ & $3.5-10$ & digitized \\
\hline $\begin{array}{l}\text { Sokolov and } \\
\text { others, } 2001\end{array}$ & IB32 & Shewanella putrefaciens & 0.1 & $3.5-10$ & digitized \\
\hline $\begin{array}{l}\text { Wightman and } \\
\text { others, } 2001\end{array}$ & $\begin{array}{l}\text { IB37A- } \\
\text { IB40C }\end{array}$ & Bacillus subtilis & 0.1 & $2.5-9$ & digitized \\
\hline $\begin{array}{l}\text { Yee and Fein, } \\
2001\end{array}$ & $\begin{array}{l}\text { IB10A- } \\
\text { IB13B }\end{array}$ & $\begin{array}{l}\text { Bacillus megaturium, } \\
\text { Streptocacous faecalis, } \\
\text { Sporosarcina urea, and } \\
\text { Staphyloccocs aureus }\end{array}$ & 0.1 & $3.9-9.5$ & $\begin{array}{l}\text { electronic } \\
\text { format }\end{array}$ \\
\hline $\begin{array}{l}\text { Cox and others, } \\
1999\end{array}$ & $\begin{array}{l}\text { IB52A- } \\
\text { IB53F }\end{array}$ & Bacillus subtilis & $0.025,0.1$ & $4-10$ & digitized \\
\hline $\begin{array}{l}\text { Daughney and } \\
\text { Fein, } 1998\end{array}$ & $\begin{array}{l}\text { IB26A- } \\
\text { IB29D }\end{array}$ & $\begin{array}{l}\text { Bacillus subtilis and Bacillus } \\
\text { licheniformis }\end{array}$ & $0.01,0.1$ & $4-12$ & digitized \\
\hline $\begin{array}{l}\text { He and Tebo, } \\
1998\end{array}$ & IB31 & $\begin{array}{l}\text { Spores of marine Bacillus, } \\
\text { SG-1 }\end{array}$ & 0.01 & $3.5-8.5$ & digitized \\
\hline $\begin{array}{l}\text { van der Wal and } \\
\text { others, } 1997\end{array}$ & $\begin{array}{l}\text { BW4- } \\
\text { BW23, } \\
\text { IB58 }\end{array}$ & $\begin{array}{l}\text { Cell walls of Rhodococcus } \\
\text { erythropolis A177, R. opacus } \\
\text { C125, Corynebacterum DSM } \\
6688, \text { C.DSM } 44016, \text { Bacillus } \\
\text { brevis ATCC } 9999\end{array}$ & $\begin{array}{l}0.001,0.01 \\
0.1,1.0\end{array}$ & $3-10$ & digitized \\
\hline $\begin{array}{l}\text { Plette and others, } \\
1995\end{array}$ & $\begin{array}{l}\text { BW1- } \\
\text { BW3 }\end{array}$ & $\begin{array}{l}\text { Rhodococcus erythropolis } \\
\text { A177 cell walls }\end{array}$ & $0.01,0.1$ & $3.5-10$ & digitized \\
\hline $\begin{array}{l}\text { Wallberg and } \\
\text { others, } 1991\end{array}$ & $\begin{array}{l}\text { IB34- } \\
\text { IB35 }\end{array}$ & Klebsiella oxytoca & $0.01,0.1$ & $3-9.2$ & digitized \\
\hline
\end{tabular}


potentiometric titration datasets (for example, Borrok and others, 2004a; Fein and others, 2005). Instead of solving for the best-fitting $\mathrm{pK}_{\mathrm{a}}\left(-\log\right.$ of $\mathrm{K}_{\mathrm{a}}$ ) values for each titration, we assign 4 separate $\mathrm{pK}_{\mathrm{a}}$ values and solve only for site concentrations for each titration. This 'fixed-pK $\mathrm{a}_{\mathrm{a}}$ ' modeling approach has been used to successfully describe the adsorption of protons and metals onto dissolved humic substances (Westall and others, 1995) and to describe protonation and metal-binding reactions in joint humic/bacteria systems (Borrok and Fein, 2004). We utilize the $\mathrm{pK}_{\mathrm{a}}$ values originally developed by Borrok and others (2004a) for bacterial consortia grown from natural settings, with values of $3.1,4.7,6.6$, and 9.0 for the four discrete functional group sites. The fixed-pK $\mathrm{a}_{\mathrm{a}}$ approach satisfies the available spectroscopic constraints in that it contains multiple sites that could be considered chemically distinct, and is also capable of describing continuous buffering capacity over a broad $\mathrm{pH}$ range. Because bacterial surfaces exhibit a continuous buffering capacity, the $\mathrm{pH}$ range of each dataset is the variable that predominantly controls the positioning of discrete $\mathrm{pK}_{\mathrm{a}}$ values, as opposed to real differences in the chemical nature of the proton binding sites. Assigning fixed $\mathrm{pK}_{\mathrm{a}}$ values, as opposed to allowing them to best-fit the data, in effect normalizes all the datasets to the same $\mathrm{pH}$ range. Hence, the fixed $\mathrm{pK}_{\mathrm{a}}$ model we present, although not unique, facilitates valid comparisons of the proton binding abilities of bacteria where titration data were collected over dissimilar $\mathrm{pH}$ ranges. To eliminate large modeling uncertainties and to facilitate meaningful comparisons over the chosen $\mathrm{pH}$ range $(\sim 3$ to $\sim 9.5$ ), datasets that did not cover the $\mathrm{pH}$ range of at least 4.0 to 8.5 were not modeled. For additional consistency, individual datapoints below $\mathrm{pH} 2.5$ or above $\mathrm{pH}$ 10.0 were also excluded.

In our modeling approach, we ignore the effects of the bacterial surface electric field on the adsorption equilibria. Our goal is to use this non-electrostatic modeling approach to quantify and compare the magnitude of ionic strength effects on the deprotonation reactions to those of other parameters that have been studied experimentally. Only after doing this can we determine which factors are important and require more detailed modeling. Our approach is intended to provide an internally consistent comparison of functional group site densities among many bacterial species and bacterial consortia, and is not meant to duplicate previous studies. Like any modeling approach, ours is a simplification of an extremely complex system, and as such is only an approximation of the mechanisms involved.

We use the program FITEQL 2.0 to solve for functional group site concentrations for each of the four discrete sites with the fixed $\mathrm{pK}_{\mathrm{a}}$ values (Westall, 1982). The relative goodness of fit of each tested model is quantified using the residual function, $\mathrm{V}(\mathrm{Y})$, from the FITEQL 2.0 output for each model. Lower $\mathrm{V}(\mathrm{Y})$ values signify better fits, and $\mathrm{V}(\mathrm{Y})$ values between 0 and 20 can generally be considered good fits (Westall, 1982). Although the charge balance equation (1) holds for every point along the titration, it does not account for the initial charge $\left(\mathrm{Q}^{\circ}\right)$ on the bacterial surface prior to beginning a titration. $Q^{\circ}$ represents the concentration of protons it would take to balance the initial charge deficiency at the start of the titration. We treat $Q^{\circ}$ as an adjustable parameter and solve for it using FITEQL (see Westall and others, 1995, and Fein and others, 2005, for more complete discussions). Activity coefficients were solved for by FITEQL, using the Davies equation.

Like the different modeling approaches used to describe the protonation framework of the bacterial surface, there is also little agreement on the best approach for visualization of acid-base titration data. Most visualization approaches fall into two categories: 1) quantification of protons added to solution as a function of $\mathrm{pH}$; and 2) quantification of protons exchanged with the surface as a function of $\mathrm{pH}$. The first approach is commonly described as the quantity ' $\mathrm{C}_{\mathrm{a}}-\mathrm{C}_{\mathrm{b}}$ ', 'concentration of $\mathrm{H}^{+}$ added', or 'equivalents of acid (or base) added', and is taken directly from the raw 
titration data. The second approach is commonly referred to as 'charge excess', 'relative charge', ' $\left[\mathrm{H}^{+}\right]$exchanged', or ' $\mathrm{H}^{+}$bound.', and is defined as the quantity, ' $Q$ ', in equation 1. Although both approaches are valid, they are often not comparable because of differences in the initial protonation state of the bacterial surface prior to the titration in each experimental study (see discussion of $Q^{\circ}$ above). Because the $Q^{\circ}$ quantity controls the relative positioning of the titration curve, all raw titration datasets would have to be corrected by this factor to achieve an internally consistent comparison. However, some studies make arbitrary assumptions in applying a correction factor for $\mathrm{Q}^{\circ}$, while most studies do not correct for this factor at all, making meaningful graphical comparisons among different studies difficult.

Because of these difficulties, we use an approach for data visualization that is not dependent upon $\mathrm{Q}^{\circ}$. This approach quantifies the proton buffering capacity of the bacterial surface as a function of $\mathrm{pH}$, and is superior to the other approaches for comparing titrations conducted under dissimilar experimental conditions. This third approach, proposed by Turner (2004) and Turner and Fein (unpublished data), uses a quantity ' $Q^{*}$ ' that we refer to as the proton buffering capacity function, which is defined below.

$$
Q^{*}=\frac{\mathrm{d}_{\mathrm{rel}}}{d\left(\log \mathrm{a}_{\mathrm{H}^{+}}\right)}=\frac{-d \mathrm{Q}_{\mathrm{rel}}}{d(\mathrm{pH})}
$$

Where $Q_{\text {rel }}$ is the relative change in surface charge per mass of absorbent. Since $Q^{*}$ is not easily calculated using an electronic spreadsheet, a computer program, ProtoFit, was developed to conduct the calculations (Turner, 2004). The computational algorithm used by ProtoFit also produces an uncertainty estimate in $Q^{*}$ for each point in the titration. Because the value of $Q^{*}$ does not depend on $Q^{\circ}$, it is a useful function for comparing datasets conducted under dissimilar experimental conditions, and is used throughout this paper for data visualization purposes.

\section{RESULTS AND DISCUSSION}

Modeling was completed for 160 of the 225 individual datasets that met all of the necessary criteria (described above). Modeling results using the four-site surface complexation approach are summarized in table 2 , and demonstrate that all the tested bacterial species and consortia possess significant buffering capacity over the $\mathrm{pH}$ range defined by the assigned $\mathrm{pK}_{\mathrm{a}}$ values. Moreover, functional group site densities for the more than 20 individual bacterial species and 16 bacterial consortia tested exhibit remarkable similarity. For example, the average total site density for all bacterial species and consortia is $3.2 \pm 1.0(1 \sigma) \times 10^{-4}$ moles/wet gram (table 2$)$. The site densities reported in our study are actually 'apparent' site densities because: (1) they have not been corrected for bacterial surface electrostatic effects (we use a nonelectrostatic model), and (2) we impose a fixed set of $\mathrm{pK}_{\mathrm{a}}$ values for which the site densities are valid. In other words, changing the chosen $\mathrm{pK}_{\mathrm{a}}$ values would also lead to minor fluctuations in the individual site densities.

The model fits for most datasets are excellent, as confirmed by the very low $\mathrm{V}(\mathrm{Y})$ values presented in table 2. Generally, the model fits are visually indistinguishable from the individual datapoints themselves. However, in some cases $\mathrm{V}(\mathrm{Y})$ values are somewhat higher, reflecting the greater modeling uncertainties in datasets that cover more limited $\mathrm{pH}$ ranges. For example, if a dataset contains no datapoints below approximately $\mathrm{pH} 3.7$, the uncertainty associated with the calculated site concentration for the site with a $\mathrm{pK}_{\mathrm{a}}$ value of 3.1 becomes large. However, despite some magnification of modeling uncertainties for datasets with limited $\mathrm{pH}$ coverage, this modeling approach is invaluable for making legitimate comparisons between all the different datasets that cover dissimilar $\mathrm{pH}$ ranges. 


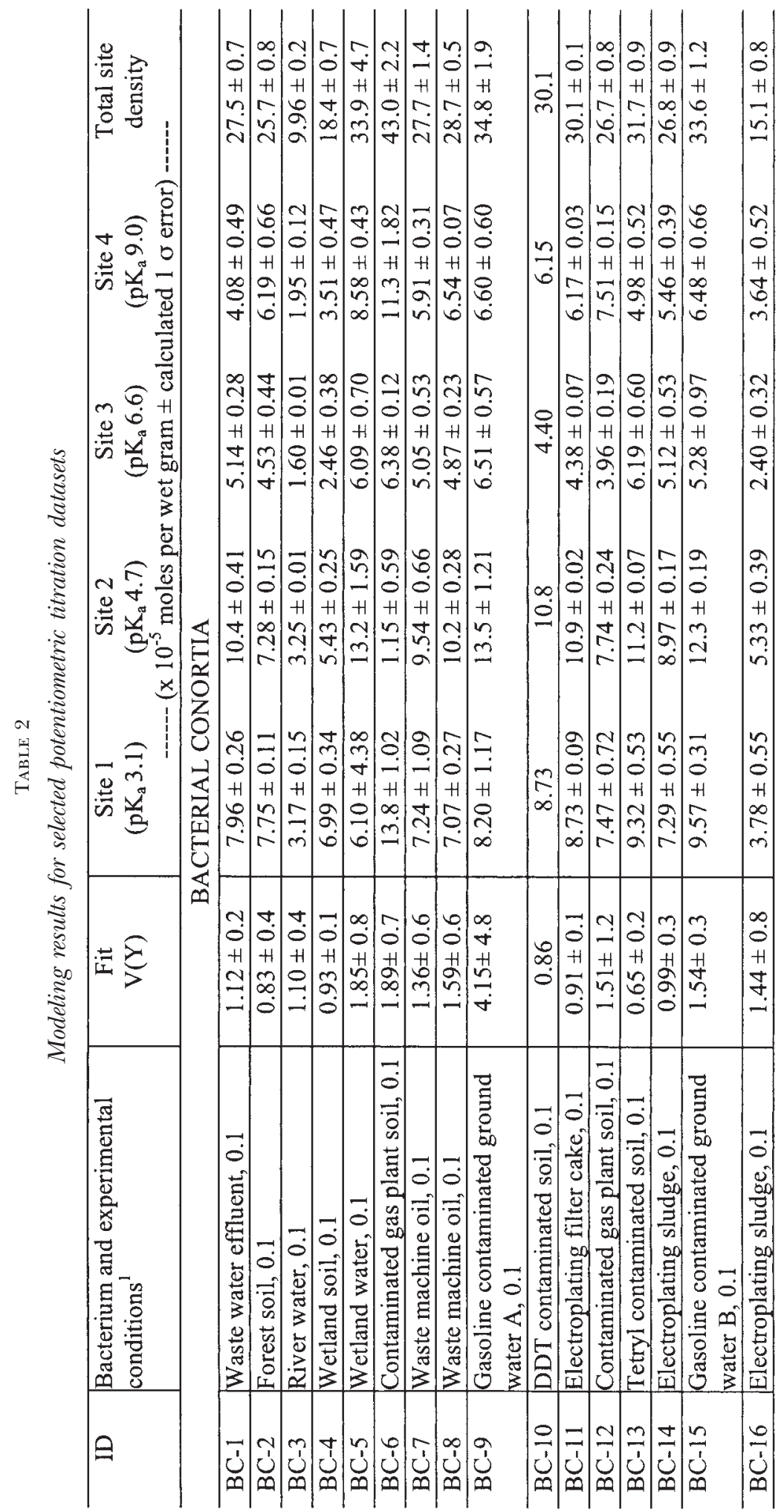




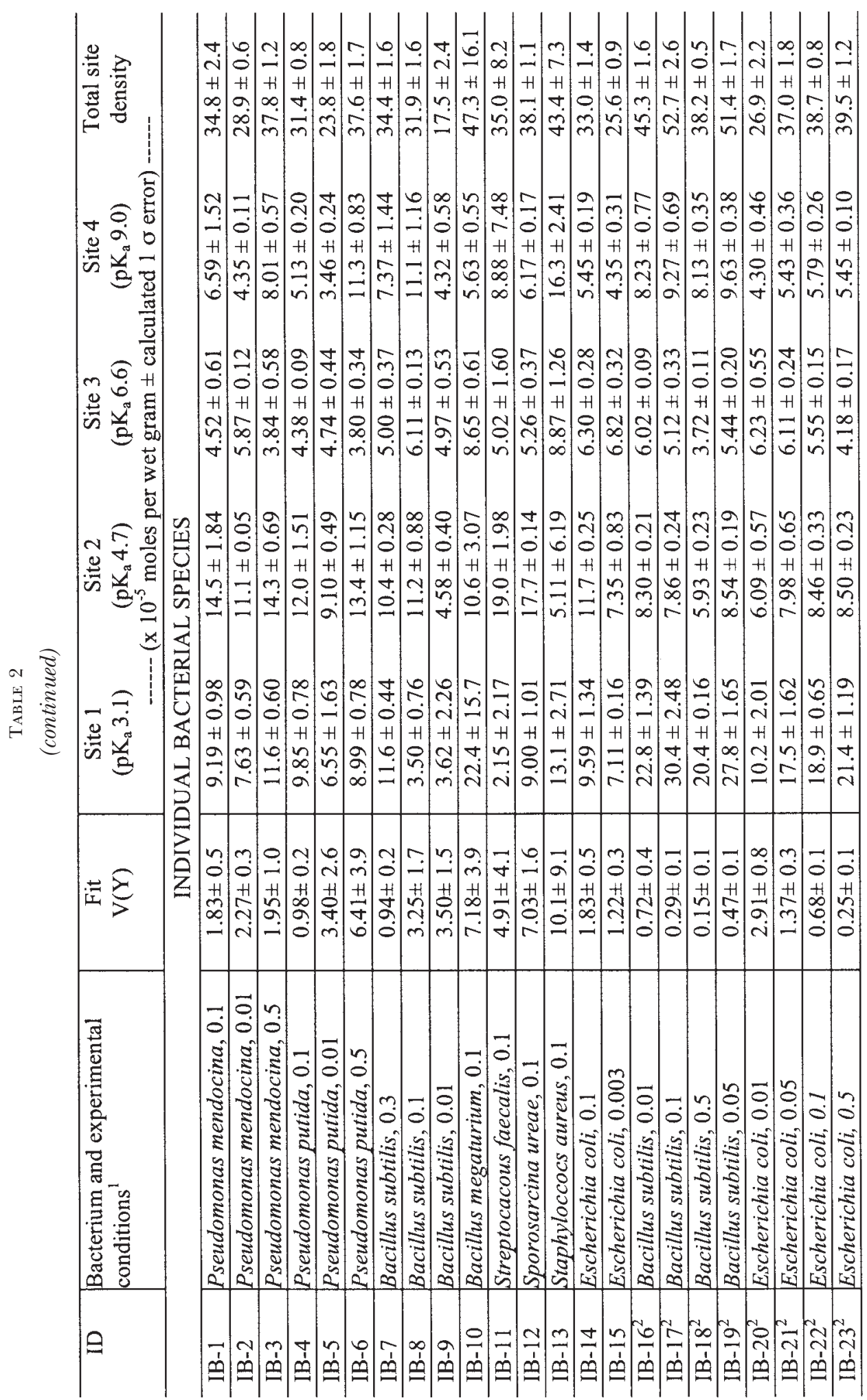




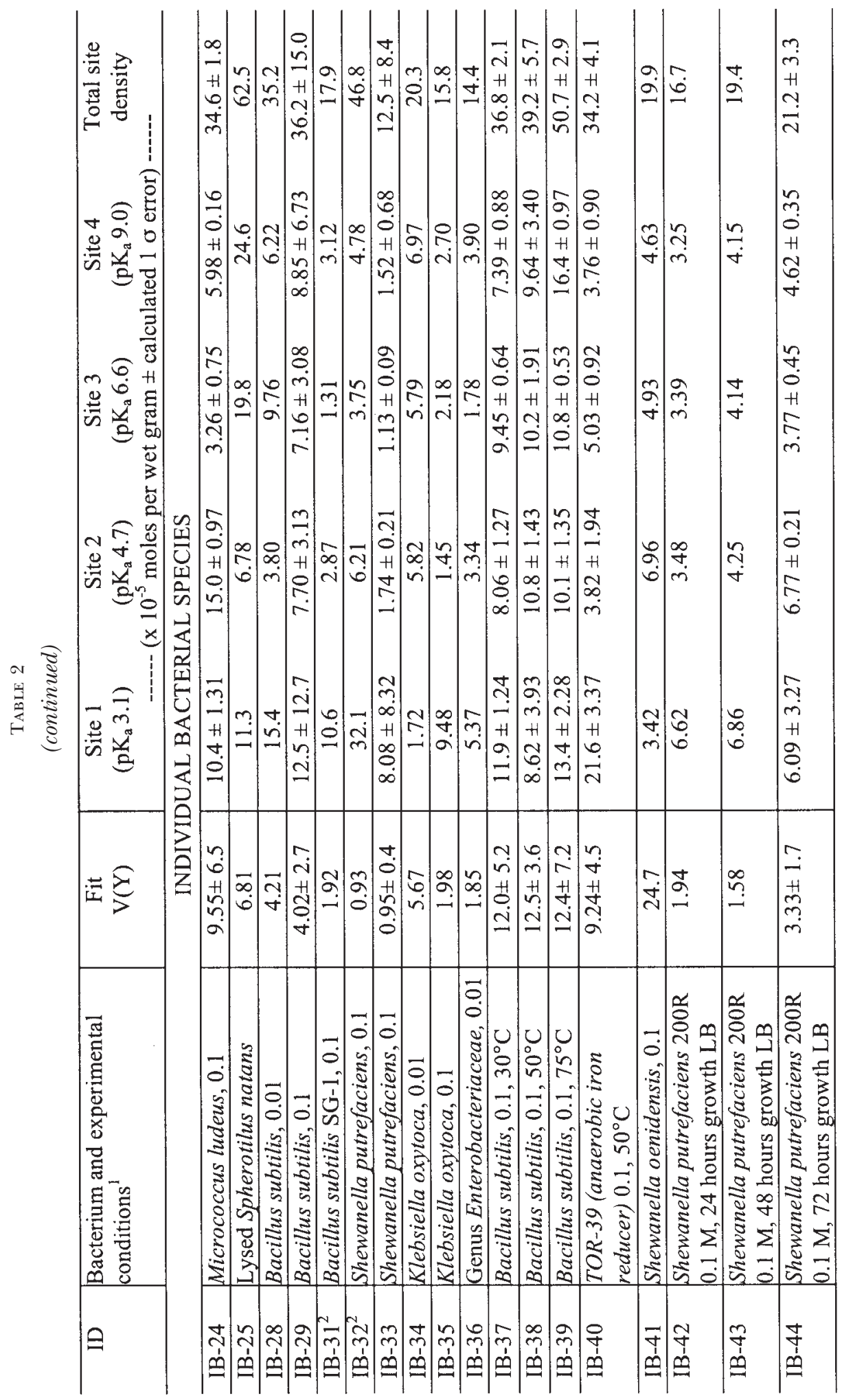




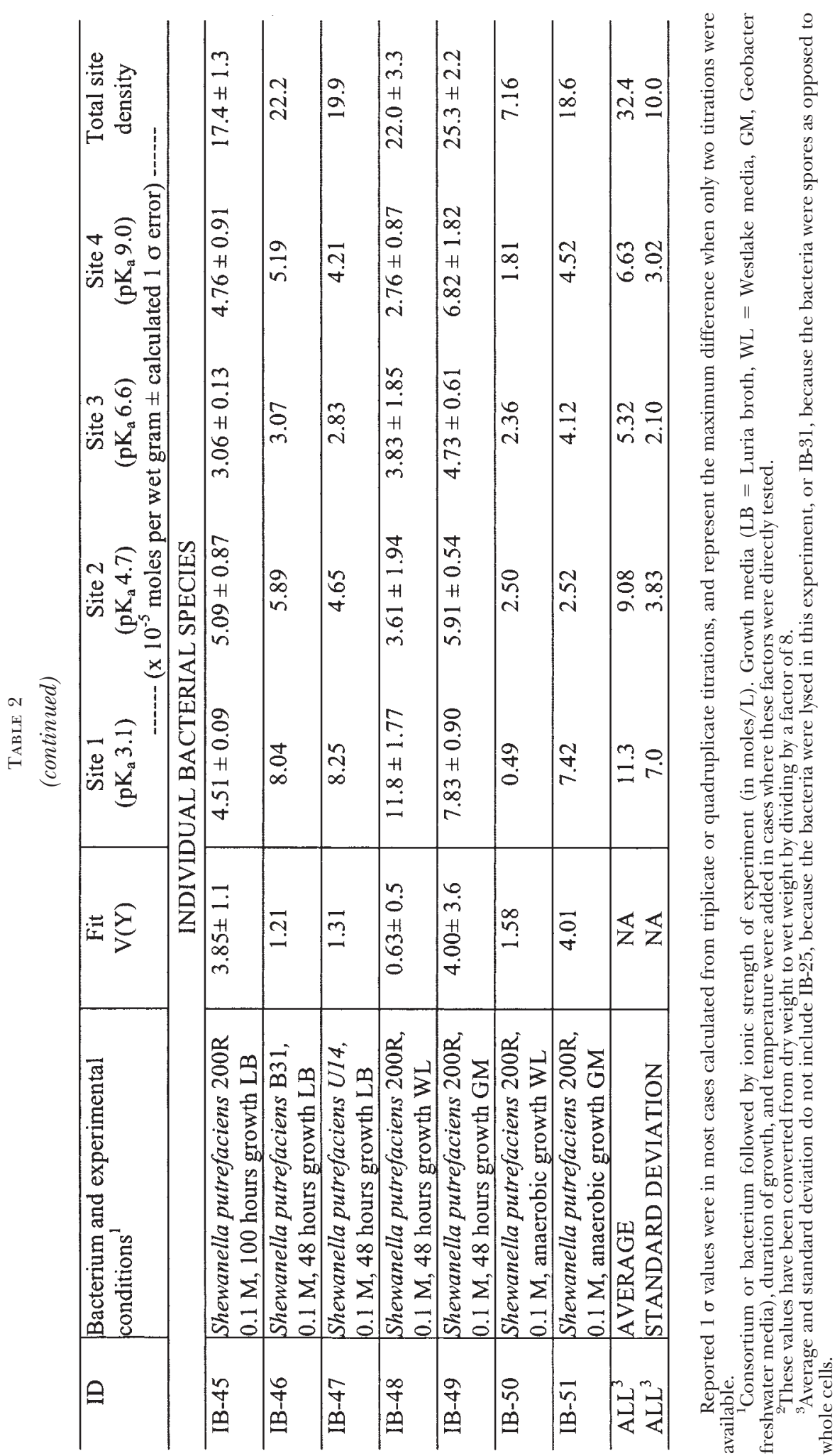


Modeling results were corroborated using a modified version of the program ProtoFit (available at http:/ / protofit.sourceforge.net/database). The functional group site densities for each of the four fixed $\mathrm{pK}_{\mathrm{a}}$ values calculated using ProtoFit are within approximately \pm 5 percent of the values calculated using FITEQL 2.0. Site density values are calculated based on a mass balance of protons using the FITEQL program, while ProtoFit calculates site density values by fitting the ProtoFit buffering function $\left(Q^{*}\right)$. Because ProtoFit calculates site density values using a completely different method, it affirms the robust nature of the FITEQL values reported in table 2. A table of values generated by ProtoFit and input files for each dataset are included with the modified version of the program on the internet.

\section{Comparisons, Uncertainties, and the Development of a Universal Model}

Factors such as ionic strength, growth medium composition, and the type of bacterial species appear to have some influence on calculated site densities. In the following sections, we discuss the magnitude of the effect on total site densities associated with these experimental variables. We quantify and compare the variability related to these factors, over the range of conditions represented in the dataset, in order to guide the development of a universal set of proton-binding modeling parameters that can serve as the framework for modeling bacterial adsorption reactions in geologic settings. For many of the parameters that we discuss below, the range of conditions represented in the dataset reasonably approximates those found in natural geologic settings. However, the variability that we quantify would potentially change as the range of conditions and bacterial species tested expands. Our goal is to determine whether application of a universal bacterial cell wall protonation model, that neglects the effects of these changing conditions, introduces acceptably small errors in estimating protonation behavior in real systems. Although many of these factors have calculable and often times predictable effects on total site density, wherever possible we report the magnitude of these effects as ' \pm coefficient of variation (CV)' values (standard deviation divided by the mean, multiplied by 100), where the range of variance represents the range of experimental conditions tested. Using this method, we are able to achieve a consistent comparison among many of the factors affecting calculated site densities. These comparisons should be considered 'best estimates' based on the available datasets, and are likely to change to some degree as new proton-binding studies become available.

Experimental variability.-Errors associated with experimental variability can be evaluated by comparing modeling results from multiple titrations of the same bacterium or consortium conducted under identical experimental conditions (replicate titrations). One $\sigma$ uncertainties based on replicate titrations are presented in table 2. Values that are shown in table 2 with no associated errors represent modeling results from single titrations, so no error analysis could be completed for these data. We calculate a CV for each of the 49 entries that included replicate titrations and average these percentage values to arrive at an average CV value of approximately \pm 9 percent. This represents the average uncertainty due to experimental errors. Experimental variability is inherent in the comparisons of the remaining experimental factors below.

Mass conversions. - Individual studies report experimental bacterial concentrations in terms of cell abundance, wet mass, or dry mass, and it is necessary for us to convert these values to a single concentration value to make valid comparisons among studies. We estimate the error associated with mass conversions based on those recently reported in the literature, and are unable to calculate a true CV for this variable.

The wet mass to dry mass ratio of whole bacterial cells is dependent upon the species of bacteria and the time and rate of centrifugation used to de-water the bacteria. Borrok and others (2004a) report wet mass to dry mass ratios ranging from 3.1:1 to 6.5:1 (averaging 5:1) in individual experiments using three Gram negative and 
two Gram positive bacteria. Fein and Delea (1999) and Daughney and others (2001) report a wet mass to dry mass ratio of 9.9:1, and 10.2:1, respectively for B. subtilis. Based on these previous studies, we use the average conversion factor of $8: 1$ for this study. This conversion factor is within 40 percent of previously measured values, suggesting that \pm 40 percent is the approximate uncertainty associated with wet/dry conversions.

Growth media and duration, temperature, and metabolic influences.-Haas (2004) conducted titrations of Shewanella putrefaciens $200 \mathrm{R}$ as a function of growth duration prior to experimentation. Our modeling of this data using the simplified 4-site approach, generates results similar to those originally generated by Haas (2004). Based on our results, we calculate a $\mathrm{CV}$ of \pm 5.5 percent in total site density from titrations of bacteria grown from 24 to 100 hours prior to experimentation. Total site density increases as a function of growth time from 24 to 72 hours, but decreases to its original level at 100 hours of growth. Daughney and others (2001) performed similar experiments using the Gram positive bacterium, Bacillus subtilis. Because these experiments were not conducted below $\mathrm{pH} 4.0$, they were not modeled as part of this study; however, the ProtoFit buffering functions for each titration in both studies are presented in figures $1 \mathrm{~A}$ and $\mathrm{B}$. The shapes and positions of the buffering functions for the Haas (2004) study do not change noticeably as a function of bacterial growth time (fig. 1A); however, the ProtoFit buffering function values for B. subtilis harvested during exponential growth phase (from the Daughney and others, 2001, study) are greater from $\mathrm{pH} 4.5$ to 7.5 than the corresponding values for B. subtilis harvested during either stationary or sporolated growth phases (fig. 1B). Haas (2004) also conducted titrations of $S$. putrefaciens 200R grown for 48 hours in different broth solutions. We model these titrations using the simplified 4-site approach and find that changes in growth media result in a CV of \pm 3.6 percent in total site density. We also model titration data from Haas (2004) collected using the facultative bacterium $S$. putrefaciens $200 \mathrm{R}$ grown anaerobically (as opposed to aerobically in the aforementioned experiments). The results show that site density decreased by about 15 percent when the bacterium was grown anaerobically in Westlake media (as compared to aerobic growth in Westlake media). Site density decreased by 72 percent when the bacterium was grown anaerobically in Geobacter Freshwater Media (as compared to aerobic growth in the same media). Differences in these results appear to reflect the different growth media used in each experiment. Moreover, because of the extended growth times necessary for anaerobic bacteria, we cannot isolate the effect of 'growth duration' on site density in these experiments. Because of these difficulties, we do not attempt to calculate a CV for this data, but estimate the approximate uncertainty to be \pm 31.5 percent based on the maximum site density change.

Wightman and others (2001) investigated the effect of temperature on the proton binding behavior of $B$. subtilis over the range of 30 to $75^{\circ} \mathrm{C}$. Our modeling results of these data demonstrate that total site densities increase with increasing temperature, resulting in a $\mathrm{CV}$ of \pm 8.8 percent over this temperature range. Although not included in table 2 because of uncertainty in conversion from cell density to wet weight, Claessens and others (2004) conducted titrations of S. putrefaciens using 2 minute and 5 minute equilibration times prior to the addition of the next aliquot of titrant. Our modeling indicates that the longer equilibration time results in an increase in apparent total site density of about $\sim 9.5$ percent (or a variability of $\pm 4.7 \%$ ) based on the difference from the average site density of the two titrations. This increase in site density appears to be related to metabolic exchange of protons within the cell membrane. However, it is not clear whether other bacterial species behave in a similar fashion.

Ionic strength.-We could find only 6 studies of potentiometric titrations of whole bacterial cells that involve ionic strength changes of at least one order of magnitude 

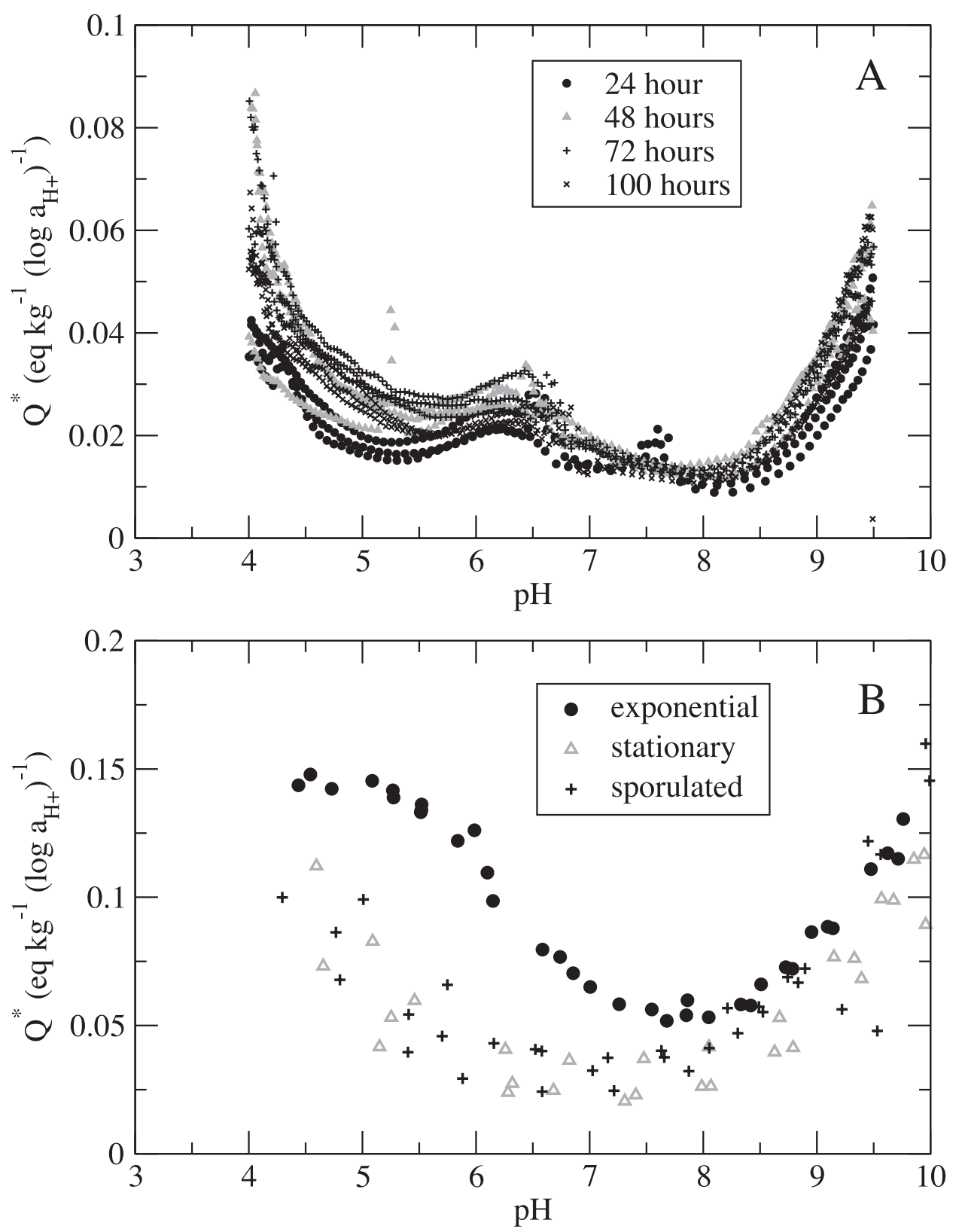

Fig. 1. The ProtoFit buffering function $\left(Q^{*}=\left(-d \mathrm{Q}_{\text {rel }} / d(\mathrm{pH})\right)\right.$, normalized per wet gram of bacteria) plotted as a function of $\mathrm{pH}$ for (A) Shewanella putrefaciens $200 \mathrm{R}$ grown for $24,48,72$, and 100 hours prior to experimentation (Haas, 2004), and (B) Bacillus subtilis harvested during exponential, stationary, and sporolated growth phases prior to experimentation (Daughney and others, 2001).

(Walberg and others, 1991; Daughney and Fein, 1998; Martinez and others 2002; Borrok and Fein, 2005; Borrok and others, 2005; Fein and others, 2005). These studies utilized the Gram positive bacteria Bacillus subtilis and Bacillus licheniformis, and the Gram negative bacteria Pseudomonas mendocina, Pseudomonas putida, Escherichia coli, and 


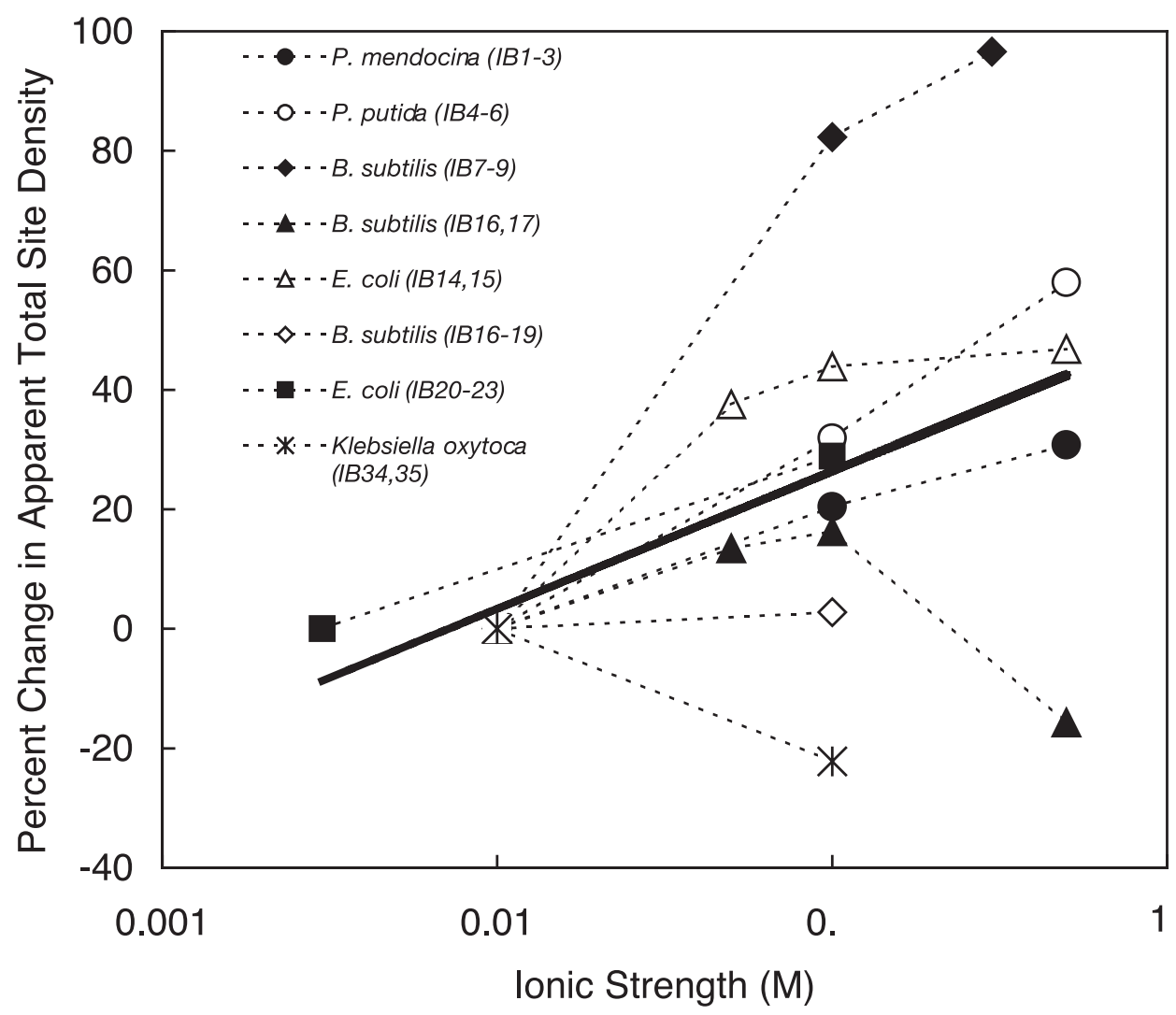

Fig. 2. Percentage change in apparent total site density for individual bacterial species as a function of ionic strength. Percentages of change for each species (within each individual study) are calculated relative to the total apparent site density calculated at the lowest experimental ionic strength of each study. Hence the lowest ionic strength datapoint for each study is assigned a value of zero. Dashed lines connect data points for individual studies. The best-fit logarithmic trend line for all the data (solid line) has a correlation coefficient of 0.27 .

Klebsiella oxytoca. Our modeling results from these studies demonstrate a general trend of increasing apparent total site density as a function of increasing ionic strength (fig. 2). The best-fitting logarithmic trend line for the entire dataset (solid line in figure 2) verifies this trend. However, the magnitude of this trend varies greatly among individual studies, and in a few cases this general relationship is contradicted, resulting in a weak correlation coefficient of 0.27 for the trend line (fig. 2).

The relationships between ionic strength and site density manifest themselves as changes in the magnitude and positioning of the ProtoFit buffering function for each titration as a function of ionic strength, and are presented for each study in figures $3 \mathrm{~A}-\mathrm{H}$. The most notable changes in the buffering functions for all but one study occur between $0.1 \mathrm{M}$ ionic strength and the lowest ionic strength reported (generally 0.01 $\mathrm{M})$. In each case, this change is distinguished by a slight reduction in the magnitude of the main buffering peak (around $\mathrm{pH} 5$ ) at low ionic strength compared to the $0.1 \mathrm{M}$ and higher ionic strengths. Additionally, at the lowest ionic strengths, the position of this buffering peak in most studies is shifted slightly to higher pH (figs. 3A-G). This shift is evident in studies of Gram positive (figs. 3A, C, D) and Gram negative bacteria (figs. 3B, E, F, G, H), suggesting that the structure of the bacterial cell wall is not a 

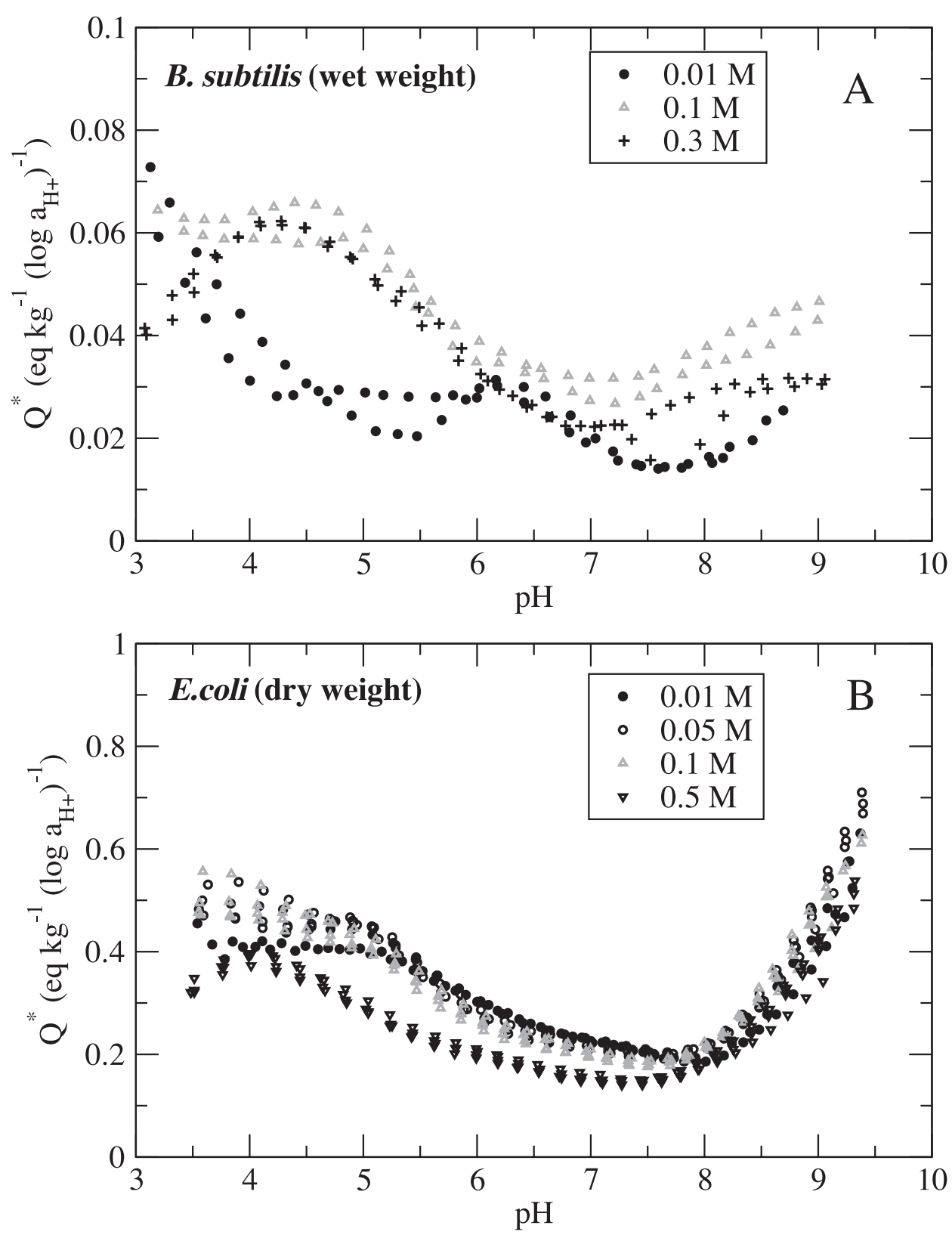

Fig. 3. The ProtoFit buffering function $\left(Q^{*}=\left(-d \mathrm{Q}_{\mathrm{rel}} / d(\mathrm{pH})\right)\right.$, normalized per originally reported wet or dry gram of bacteria used in each experiment) plotted as a function of $\mathrm{pH}$ for (A) Bacillus subtilis at ionic strengths of $0.01,0.1$, and $0.3 \mathrm{M}$ (Fein and others, 2005); (B) Escherichia coli at ionic strengths of 0.01, 0.05, 0.1 , and $0.5 \mathrm{M}$ (Martinez and others, 2002).

critical factor in how ionic strength affects protonation reactions on the bacterial surface (a conclusion also supported by Borrok and Fein, 2005). In contrast to the other results, the ProtoFit buffering function for E. coli in the Martinez and others (2002) study shows little change over the ionic strength range $0.01 \mathrm{M}$ to $0.1 \mathrm{M}$, but 

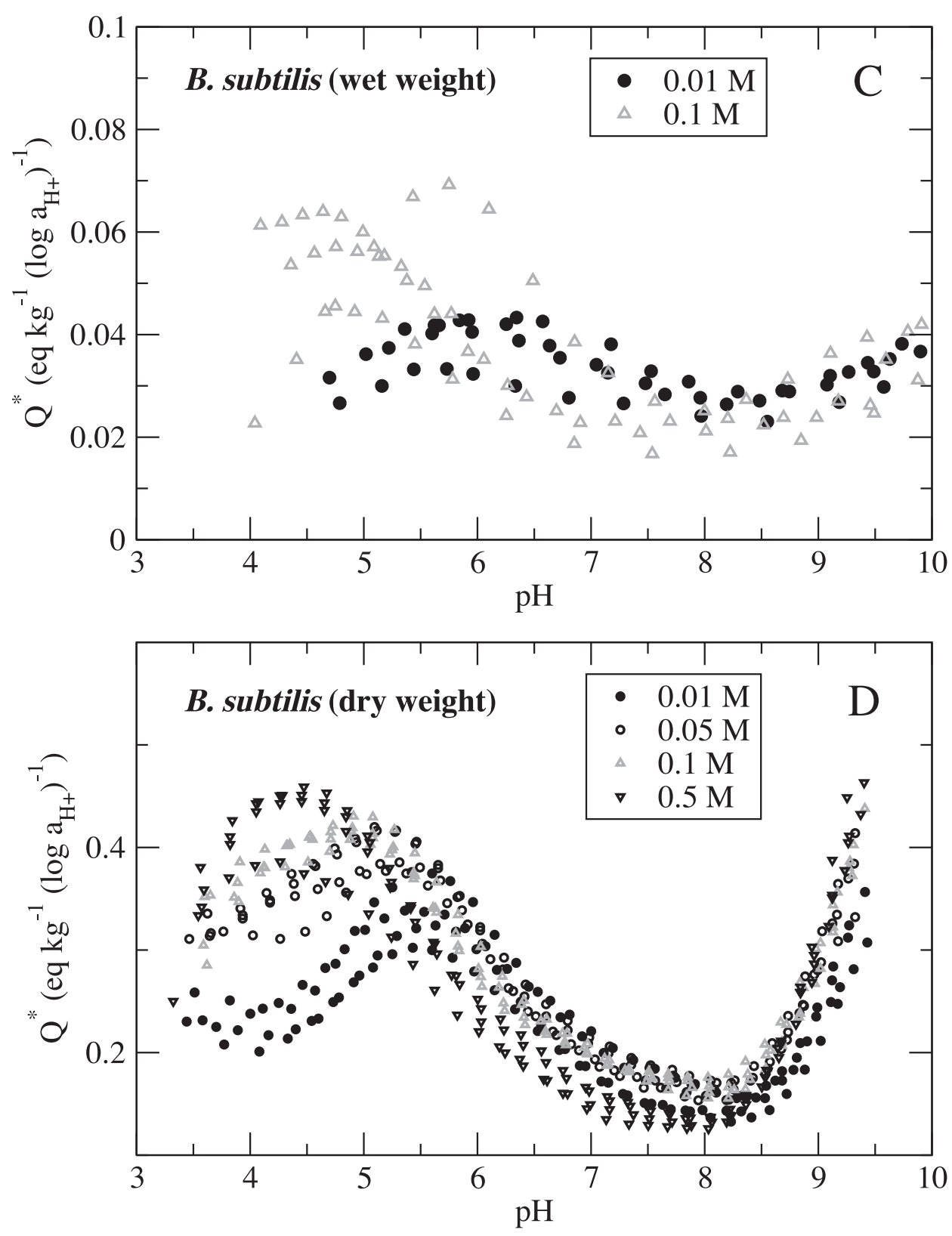

Fig. 3. (continued) (C) B. subtilis at ionic strengths of 0.01, and 0.1 M (Daughney and Fein, 1998); (D) B. subtilis at ionic strengths of $0.01,0.05,0.1$, and $0.5 \mathrm{M}$ (Martinez and others, 2002); (E) E. coli at ionic strengths of 0.003 and $0.1 \mathrm{M}$ (Borrok and others, 2005).

exhibits a shift in magnitude (lower) for the $0.5 \mathrm{M}$ case. We calculate the average CV due to ionic strength effects over the ionic strength ranges represented in each individual study by calculating the 'standard deviation/mean*100' for each set of titrations and averaging them over the 6 studies. The average CV $( \pm 8.5 \%)$ is partly a reflection of the range of ionic strength conditions tested in each of the individual 

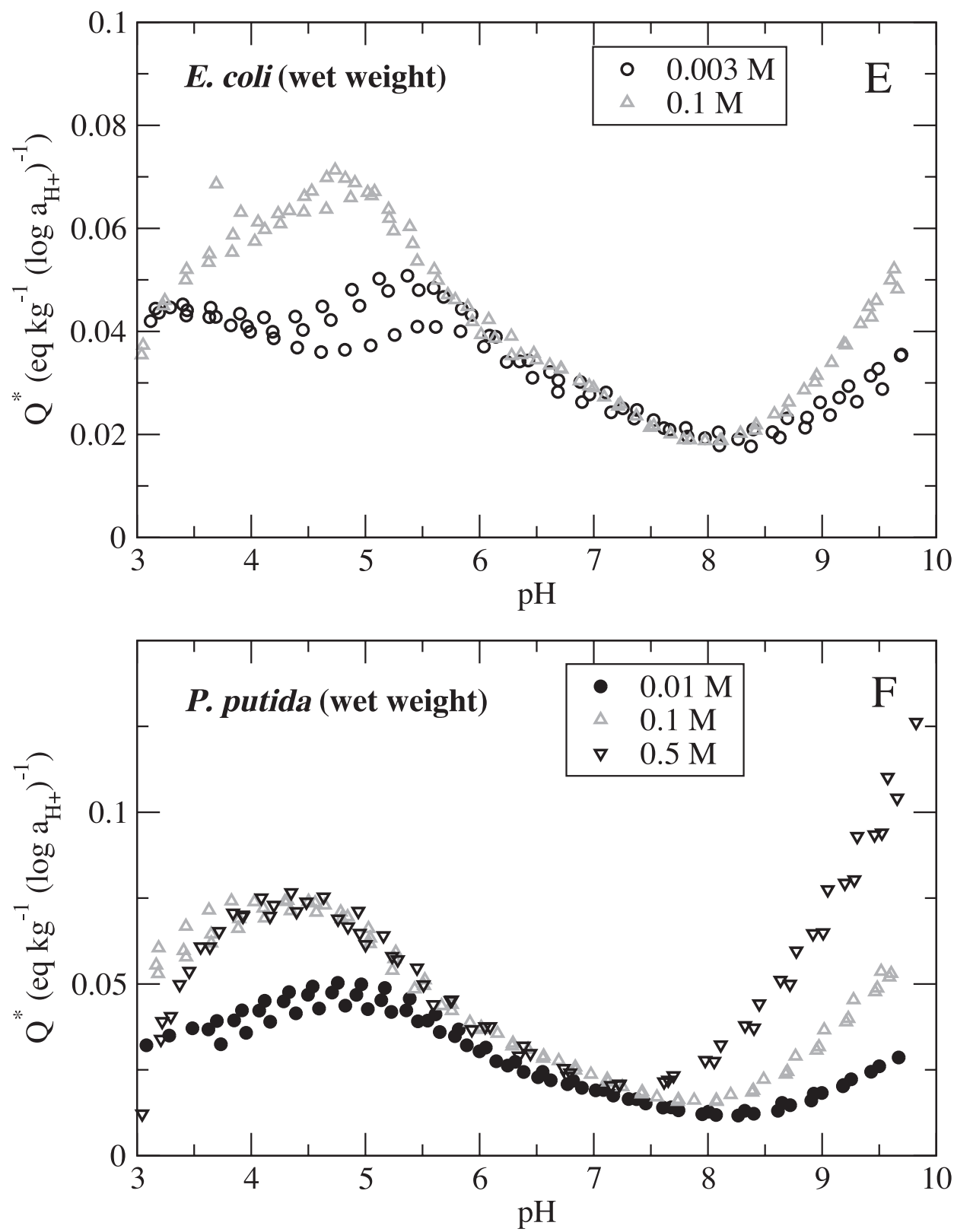

Fig. 3. (continued) (E) E. coli at ionic strengths of 0.003 and $0.1 \mathrm{M}$ (Borrok and others, 2005); (F) Pseudomonas putida at ionic strengths of 0.01, 0.1, and 0.5 M (Borrok and Fein, 2005).

studies, and is likely to change somewhat as more studies are performed and broader ranges of ionic strength are tested. For a more direct comparison among these studies, we normalize the individual CV values per $1 \log$ unit change in ionic strength. The normalized results demonstrate that the average effect of ionic strength is a 12.5 percent increase in apparent site density per one order of magnitude increase in ionic strength. 

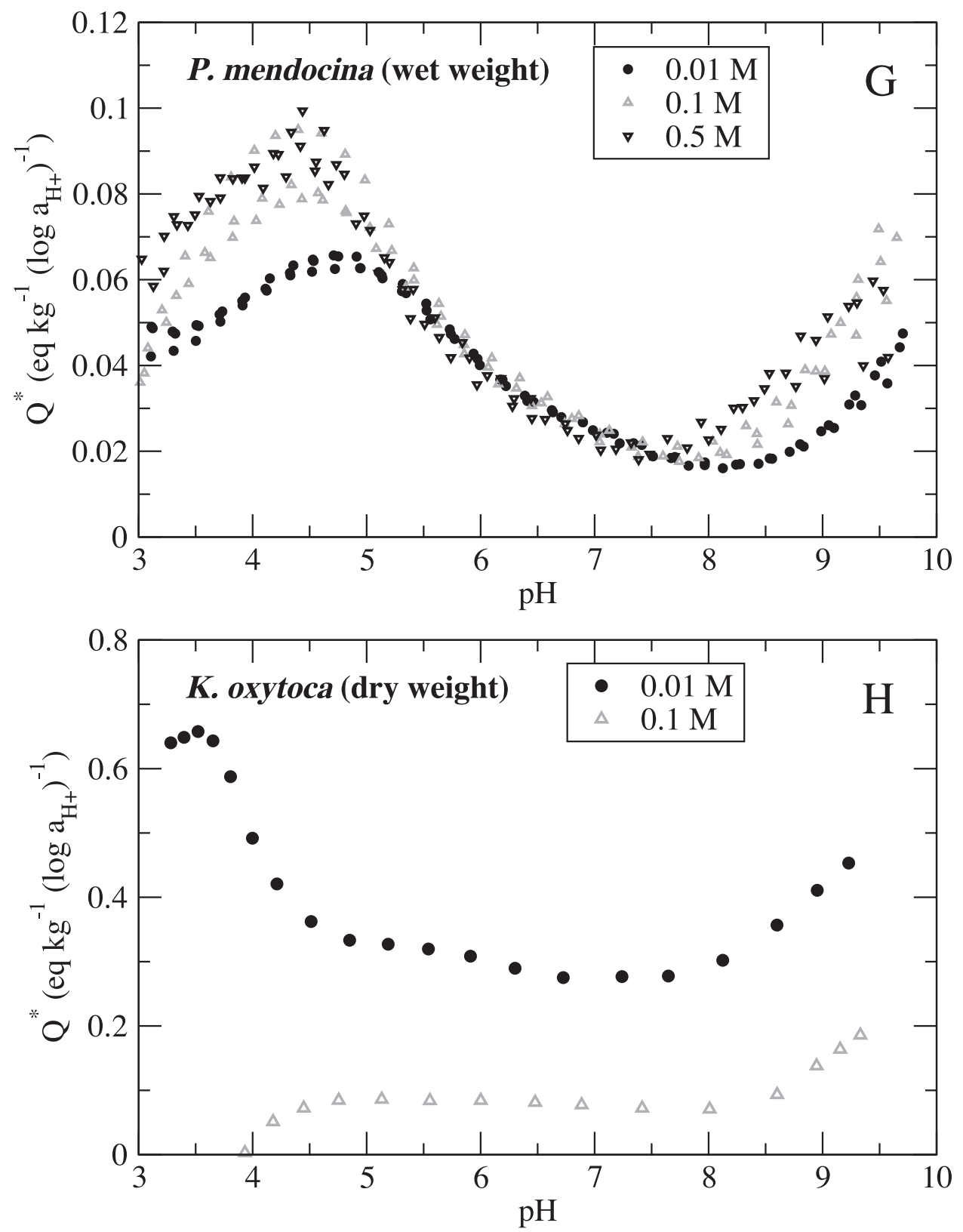

Fig. 3. (continued) (G) Pseudomonas mendocina at ionic strengths of $0.01,0.1$, and $0.5 \mathrm{M}$ (Borrok and Fein, 2005); (H) Klebsiella oxytoca at ionic strengths of 0.01 and $0.1 \mathrm{M}$ (Wallberg and others, 1991). For the modeling compilation in table 2 , dry mass has been converted to wet mass by using a factor of 1 dry gram $=8$ wet grams.

Electrostatic treatments. - Changes in the protonation behavior of the bacterial surface as a function of ionic strength (figs. 2, 3A-H) are likely caused by changes in the electric double layer which affect the activity of the bacterial surface species. Hence, the changes in apparent site densities as a function of ionic strength (fig. 2, table 2) can 
likely be accounted for to some degree by utilizing corrections that account for non-ideal behavior that arises from these electrostatic interactions. However, it remains unclear which electrostatic treatment is best and whether the ionic strength effects are large or consistent enough to require any treatment at all other than the alternative (which we employ in this study) of using a non-electrostatic model that neglects the effects of the surface electric field. For example, Martinez and others (2002) conducted titrations over a broad ionic strength range using whole cells of $B$. subtilis and E. coli. They successfully applied the Donnan electrostatic model to protonation reactions using a master curve approach, noting an improvement in the residual scatter of titration datapoints after application of the Donnan model. Borrok and Fein (2005) applied diffuse layer and triple layer electrostatic models to titration data collected over a broad range of ionic strengths using $P$. mendocina and P. putida. They demonstrate that these electrostatic treatments greatly over-predict the effect of ionic strength on bacterial surface protonation reactions, resulting in poorer fits and more variability in stability constants than non-electrostatic models.

The activities of bacterial surface and aqueous species change in the presence of the surface electric field surrounding the bacterial cell wall. Electrostatic treatments such as the triple layer model are often used to correct for changes in activity caused specifically by the surface electric field around mineral surfaces, while activity coefficients are used to account for changes in the activity of aqueous species caused by ionic interactions and the ordering of water molecules. Because the magnitude and geometry of the electric field surrounding the bacterial surface are unknown, it is not clear whether electric surface field models are necessary or what form these models would take. In order to test a simple approximation of the electric field effects, we consider the deprotonated bacterial surface sites as aqueous anions, and we calculate their activity coefficients using the Davies equation within FITEQL. Using this approach, we re-modeled all of the ionic strength datasets (modeling results not depicted). We find that assigning activity coefficients to deprotonated surface sites has little impact on calculated site concentrations using our 'fixed $\mathrm{pK}_{\mathrm{a}}$ ' modeling approach. For example, at $0.5 \mathrm{M}$ and $0.01 \mathrm{M}$ ionic strengths the addition of activity coefficients lowers the apparent total site density for $P$. putida by only 1.5 percent and 0.02 percent, respectively. We additionally test the impact of assigning activity coefficients for deprotonated sites by allowing both $\mathrm{K}$ values and site concentration values to float. In this case, inclusion of activity coefficients for deprotonated sites serves to slightly decrease the magnitude of the apparent $\mathrm{K}$ values (relative to their pre-activity coefficient values), with an increasing effect with increasing ionic strength. Calculated site densities in this case remain relatively unaffected as a function of ionic strength. For these activity corrections to account for the observed ionic strength effects, the apparent $\mathrm{K}$ values would have to shift in magnitude enough to cause calculated apparent total site densities to merge towards one unique value over the range of ionic strengths tested. However, because the shift in $\mathrm{K}$ values using this approach is so small, we conclude that traditional activity coefficients for aqueous ions cannot account for the changes in bacterial surface protonation behavior with ionic strength. Moreover, the ionic strength effects on bacterial surface protonation behavior that have been measured to date are weak at best and probably do not warrant an electrostatic treatment to account for them (see fig. 2). We conclude from this test, and from our consideration of the ionic strength datasets, that our approach of neglecting electrostatic corrections yields a reasonable estimation of the protonation behavior of the bacterial surface as a function of ionic strength.

Cell wall structure and species. - Gram positive bacterial cell walls are composed largely of a rigid network of peptidoglycan often accompanied by teichoic acid, while Gram negative cell walls contain a much thinner layer of peptidoglycan surrounded by 
an outer membrane composed of lipopolysaccharides, phospholipids, and proteins (Beveridge, 1989). Differences in these cell wall structures may impact the types, locations, and abundances of functional group sites. However, it is impossible to fully separate the impact of 'differences in bacterial species' from 'differences in cell wall structure' on total apparent site densities. Hence, we employ a slightly different approach to our calculations that allows us to estimate the individual effects of these factors.

To quantify the effect of cell wall structure on total site density, we compare model results from separate titrations of Gram negative and Gram positive bacteria. We limit the comparison to model results from datasets collected at $0.1 \mathrm{M}$ ionic strength, at room temperature, with less than 48 hours aerobic growth time to remove the effects of these other parameters. To further isolate the effect of cell wall structure and to minimize modeling uncertainties introduced by mass conversion calculations, we examine modeling results originally reported 'per wet mass' separately from those originally reported 'per dry mass' (and later converted to wet mass). Gram positive bacteria that fit these criteria (and were originally reported per wet mass) include 6 different species, and 7 datasets (IB-8, IB-10, IB-11, IB-12, IB-13, IB-24, and IB-29, table 2). Gram negative bacteria that fit these criteria (and were originally reported per wet mass) include 6 different species, and 8 datasets (IB-1, IB-4, IB-14, IB-33, IB-41, IB-43, IB-46, and IB-47, table 2). The average total site densities for the Gram positive and Gram negative bacteria modeled are $3.8 \pm 0.5(1 \sigma) \times 10^{-4}$ and $2.4 \pm 0.8(1 \sigma) \times 10^{-4}$ moles/wet gram, respectively. This translates into a 1.6:1 Gram positive to Gram negative ratio for total site density. The bacteria used in titrations that were originally reported per dry mass, include the Gram positive bacterium, B. subtilis (IB-17) and 4 separate Gram negative bacteria (IB-22, IB-32, IB-35, and IB36, table 2). The average total site densities for the Gram-positive and Gram negative bacteria modeled (converted to wet mass using a factor of 8 to 1$)$ are $5.3 \times 10^{-4}$ and $2.9 \pm 1.6(1 \sigma) \times 10^{-4}$ moles/wet gram, respectively. This translates into a 1.8:1 Gram positive to Gram negative ratio for total site density. Averaging these results reveals that the total site densities for Gram negative bacteria are approximately 40 percent less than those for Gram positive bacteria (an approximate uncertainty of $\pm 20 \%$ ) on a mass basis. Hence, it appears that Gram positive bacteria generally have more functional group sites present on their cell walls than do Gram negative bacteria, supporting the interpretation that most functional group sites are found within the peptidoglycan layer of the bacterial cell wall. Comparisons of the ProtoFit buffering functions of Gram negative and Gram positive bacterial species are presented in figures $4 \mathrm{~A}$ and $4 \mathrm{~B}$. The shapes and positions of the Gram positive buffering functions are generally similar to those of the Gram negative species studied. However, the position of at least a subset of the Gram positive buffering functions exhibit a buffering peak at $\mathrm{pH} 4.5$, which is positioned at a slightly higher $\mathrm{pH}$ than the peaks of the buffering functions for most Gram negative bacterial species.

The magnitude of the variation in site densities among the bacterial species within each Gram type (and mass category) is likely to be of similar magnitude to the variation in site densities that one might expect among individual bacterial species in natural geologic settings. We calculate the average CV associated with differences among species by first calculating the CV within each Gram type (and originally reported mass type), and then averaging these totals. The average variance values we develop using this method quantify the uncertainty inherent in assuming that each individual species behaves in one averaged fashion. Site densities among individual bacterial species vary by an average of about \pm 34 percent (figs. $4 \mathrm{~A}$ and $4 \mathrm{~B}$ display the magnitude in variation among individual species). 

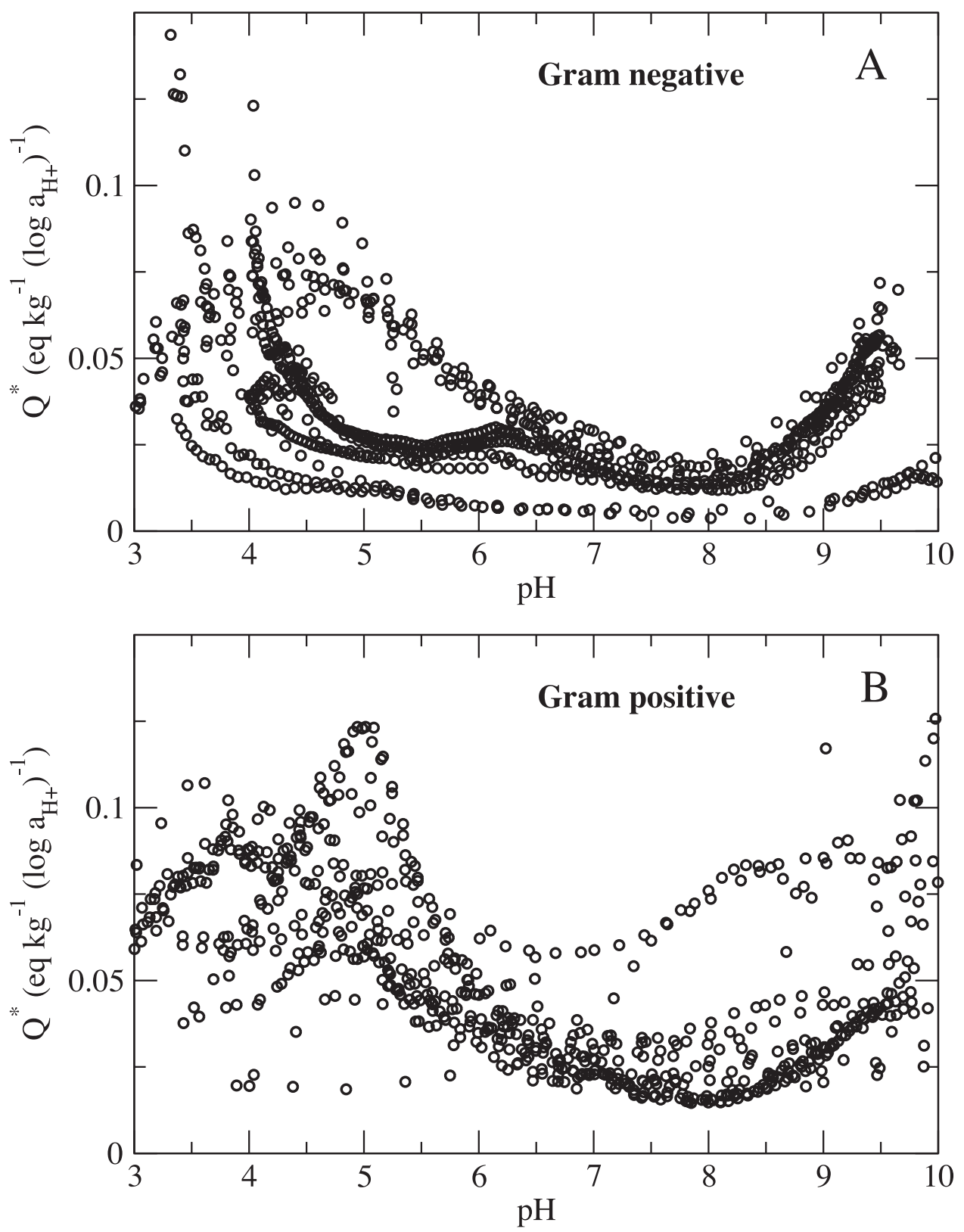

Fig. 4. The ProtoFit buffering function $\left(Q^{*}=\left(-d \mathrm{Q}_{\text {rel }} / d(\mathrm{pH})\right)\right.$, normalized per wet gram of bacteria) plotted as a function of $\mathrm{pH}$ for (A) 6 Gram negative bacterial species (see text for details), and (B) 6 gram positive bacterial species (see text for details). The mass of bacteria used to normalize each plot was originally reported as a wet mass.

As expected, the bacterial consortia, many of which contained both Gram negative and Gram positive bacteria, exhibit an average total site density between that calculated for the different Gram types $\left(2.8 \pm 0.8 \times 10^{-4}\right.$ moles/wet gram consortium). The ProtoFit buffering functions for titrations of the 16 bacterial consortia 


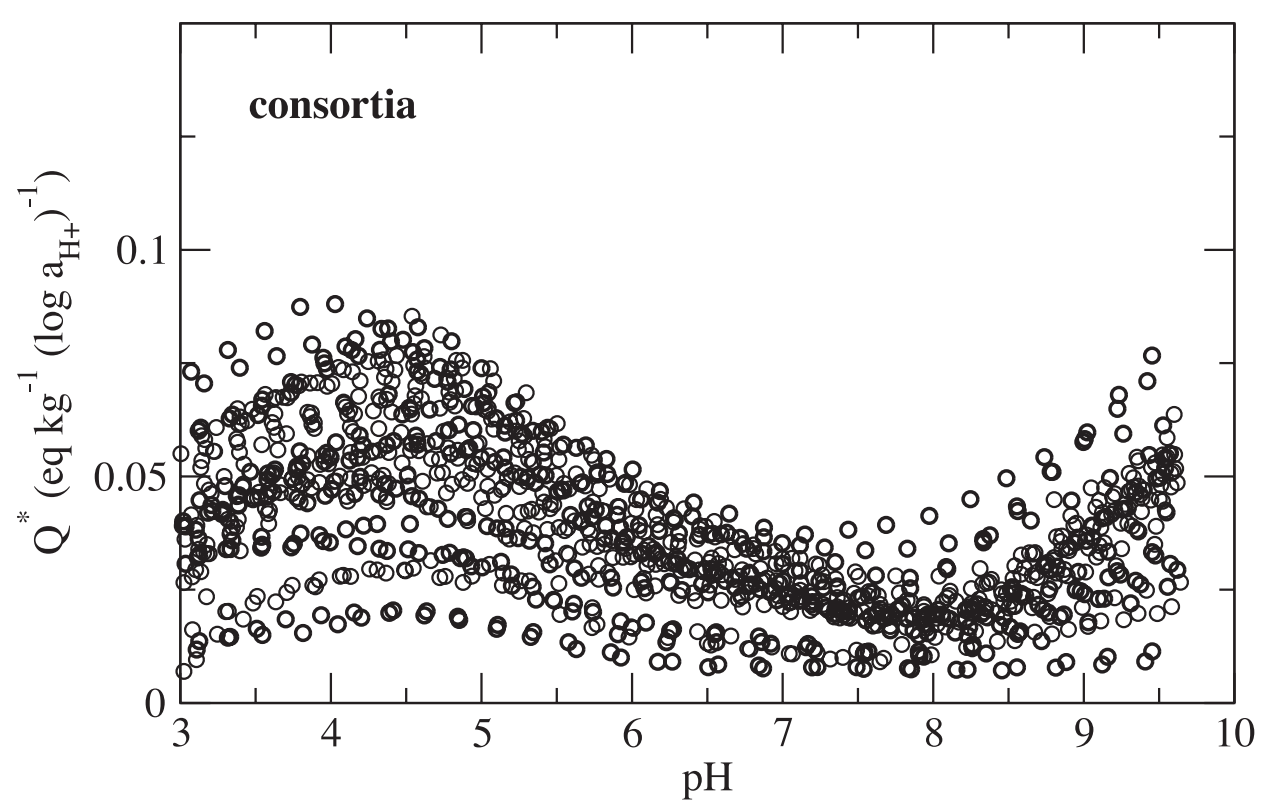

Fig. 5. The ProtoFit buffering function $\left(Q^{*}=\left(-d \mathrm{Q}_{\mathrm{rel}} / d(\mathrm{pH})\right)\right.$, normalized per wet gram of bacteria $)$ plotted as a function of $\mathrm{pH}$ for (A) 16 different bacterial consortia from a broad range of geologic and industrial settings (see text for details). The mass of consortia used to normalize each plot was originally reported as a wet mass.

modeled in this study are presented in figure 5. The shapes of the buffering functions for bacterial consortia are remarkably consistent, and only the magnitude of the buffering function changes for the different consortia. Not surprisingly, the magnitude of the buffering function for bacterial consortia lies largely within the limits defined in figures $4 \mathrm{~A}$ and $4 \mathrm{~B}$ for individual species of Gram positive and Gram negative bacteria.

Application to geologic settings. - No matter how robust a universal set of bacteria proton binding modeling parameters may be, application of these parameters to models of geologic systems requires knowledge of the total bacterial abundance in each environment of interest. In other words,

$$
\left[\text { tot } \mathrm{C}_{\text {field }}\right]=[\text { totC }] *\left[\mathrm{M}_{\text {bacteria }}\right]
$$

where $\left[\right.$ totC $\left._{\text {field }}\right]$ is the total concentration of bacterial surface functional group sites in a specific field setting (per unit volume), [totC] is the total number of bacterial surface sites per gram of bacteria, and $\left[\mathrm{M}_{\text {bacteria }}\right]$ is the mass of bacteria in the specified field setting (per unit volume). Our study quantifies the uncertainty associated with [totC] over the range of experimental conditions tested. However, the measurement of total bacterial abundance in real systems $\left[\mathrm{M}_{\text {bacteria }}\right]$ is not a straightforward task, and therefore has large uncertainties associated with it as well. Methods such as plate counting and most probable numbers are likely to underestimate bacterial abundance by as much as an order of magnitude (Zweifel and Hagstrom, 1995). More accurate, but laborious, direct counting methods have shown that bacterial abundance within the same aquifer or surface water system may vary by more than an order of magnitude, depending upon the sample location (Martino and others, 1998; Haveman and others, 1999; Almeida and others, 2001). Bacterial abundance has also been shown to change 
dramatically in response to seasonal changes (Fisher and others, 1998). Based on these studies, we estimate the uncertainty associated with $\left[\mathrm{M}_{\text {bacteria }}\right]$ to be approximately \pm half an order of magnitude ( $\pm 0.5 \mathrm{log}$ units).

Neglecting factors such as ionic strength, temperature, and growth phase of the bacterial species in applying a universal protonation model introduces relatively insignificant uncertainties compared to the uncertainties estimated for the determination of field abundances of bacteria. Figure $6 \mathrm{~A}$ compares the magnitude of the relative uncertainties in laboratory measurements ([totC]) with our estimate of uncertainty for bacterial abundance $\left(\left[\mathrm{M}_{\text {bacteria }}\right]\right)$. The elements of this comparison are derived by first re-calculating the standard deviation of the average of the total functional group site densities for all bacterial species (for all datasets analyzed in this study) on a logarithmic scale $(\log [$ totC] $)$, due to the logarithmic nature of the uncertainties associated with measurements of $\left[\mathrm{M}_{\text {bacteria }}\right]$. This error value for [totC] of $\pm 0.16 \log$ units can then be directly compared to our estimated uncertainty in bacterial abundance of \pm $0.5 \mathrm{log}$ units. The total uncertainty in the concentration of functional group sites $\left(\left[\operatorname{tot}_{\text {field }}\right]\right)$ is then $\pm 0.66 \log$ units $\left(\log [\operatorname{tot} \mathrm{C}]+\log \left[\mathrm{M}_{\text {bacteria }}\right]\right)$. Figure $6 \mathrm{~A}$ demonstrates that the uncertainty associated with determining bacterial abundances in real systems likely is much larger than the uncertainty in the development of [totC] from laboratory experiments. In our example, 76 percent of the total uncertainty ( $\left[\operatorname{tot}_{\mathrm{field}}\right]$ ) is attributable to 'field application' (or $\left[\mathrm{M}_{\text {bacteria }}\right]$ ), whereas only 24 percent of the total uncertainty is attributable to laboratory measurements (or [totC]). Figure 6B illustrates the relative contributions to [totC] for each of the individual factors examined in this study. This is a semi-quantitative comparison based on the relative proportions of the CV and 'approximate uncertainty' values developed for these individual factors. We make the simplifying assumptions that these are the only contributing factors and they influence uncertainties independently. Figure 6B demonstrates that factors such as growth media, metabolic influences, growth phase, ionic strength, temperature, and experimental uncertainties, have only a minor effect on model development. The largest uncertainties related to model development are Gram type, anaerobic versus aerobic growth, species type, and weight conversion, with each factor responsible for 13 percent, 19 percent, 20 percent, and 25 percent of the total uncertainty in figure $6 \mathrm{~B}$, respectively. Obviously a more complete titration dataset would yield more accurate estimates for the uncertainties associated with [totC]. For example, titrations have been performed using a relatively exclusive group of bacterial species, which can be grown easily under laboratory conditions. These bacterial species constitute only a small fraction of the bacterial diversity in natural settings, and the uncertainty in [totC] could increase as more species are tested.

\section{CONCLUSIONS}

In this study we compile all useable, currently available potentiometric titration datasets for bacteria, which include 225 datasets representing more than 9,000 individual data points. This is the first compilation of its kind for bacteria and can be found in spreadsheet form at 'http://protofit.sourceforge.net/database'. We model many of the datasets within this compilation using a universal 4 discrete site surface complexation framework, quantifying the concentration of proton active functional groups for each of the four discrete sites. Using this approach, we are able for the first time to directly compare the proton-binding character of a diverse range of bacterial species under many different experimental conditions (that is, ionic strength, growth media, temperature, et cetera). Despite the broad range of bacterial species and experimental conditions, modeling results for all studies are remarkably similar. For example, total functional group site densities of all the bacterial species average $3.2 \pm$ $1.0(1 \sigma) \times 10^{-4}$ moles/wet gram. The average site densities for the four discrete sites, averaged over the entire dataset, are $1.1 \pm 0.7 \times 10^{-4}, 9.1 \pm 3.8 \times 10^{-5}, 5.3 \pm 2.1 \times$ 

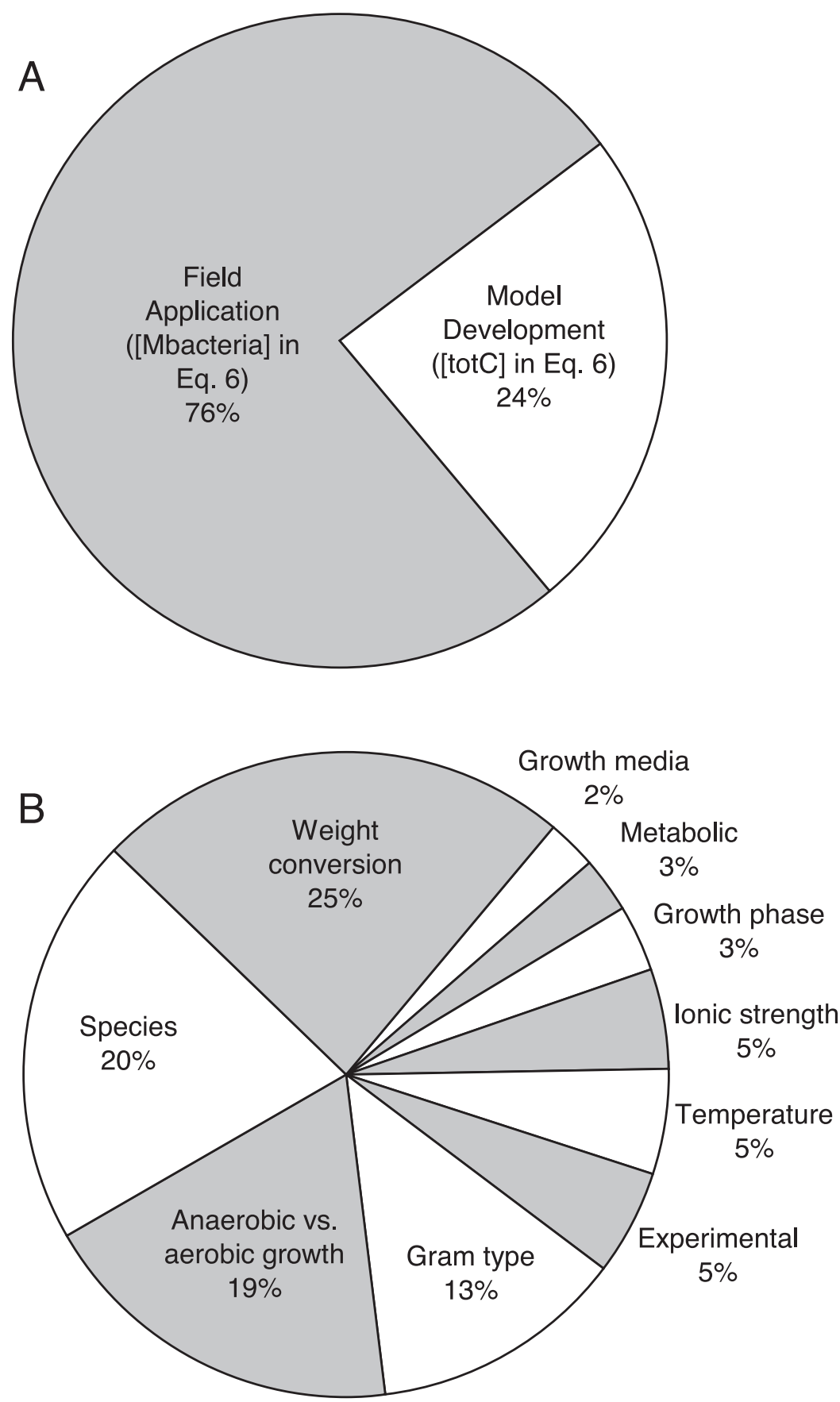

Fig. 6. (A) Comparison of uncertainties associated with the development of a universal proton-binding model, [totC], to the uncertainty inherent in the determination of bacterial abundances in geologic settings, $\left[\mathrm{M}_{\text {bacteria }}\right]$, and (B) the approximate relative contributions to the uncertainty in model development ([totC]) for each of the individual laboratory factors described in this study. 
$10^{-5}$, and $6.6 \pm 3.0 \times 10^{-5}$ moles / wet gram bacteria for the sites with $\mathrm{pK}_{\mathrm{a}}$ values of 3.1, 4.7, 6.6, and 9.0, respectively. Hence, when modeling bacterial surface protonation, ignoring factors such as species type, ionic strength, temperature, and growth conditions introduces relatively small uncertainties compared to the unavoidable uncertainty associated with the determination of cell abundances in realistic geologic systems. Our results also suggest that a broad range of bacterial surfaces exhibit 'universal' proton binding behavior over a broad range of conditions. This conclusion is consistent with the findings of Jiang and others (2004) who demonstrate through infrared spectroscopy that the cell surface functional group chemistry of a number of Gram positive and Gram negative bacterial cell walls are identical, and that this chemistry does not change as a function of growth phase or growth medium. Despite these striking similarities, there may be instances where more accurate estimates of the cell wall protonation behavior for a specific bacterial species are required. For example, in engineered systems such as bioreactors, the number of bacterial species is often limited and known, and the total bacterial abundance can be accurately determined. In these highly controlled settings, more accurate estimates of cell wall protonation behavior can be made by considering at least some of the factors that we neglect in our proposed universal model.

The conclusion that the protonation behavior of bacterial surfaces can be approximated using a single, discrete-site modeling framework with common parameters represents a step forward in our ability to model bacterial adsorption reactions in complex multi-component systems. Using the assumption of universality of proton binding behavior, we can use the single set of equilibrium constants and site concentrations determined in this study to describe bacterial protonation reactions in any geologic system of interest. Without this type of generalized approach, it would be necessary (but nearly impossible) to identify, enumerate, and perform experiments on every bacterial species present in a given geologic setting, under every condition of interest. It is our hope that the thermodynamic framework for modeling bacteriaproton binding reactions established in this study will also provide the basis for rigorous comparisons of metal binding constants among different bacterial species. If universal constants can also be developed for bacteria-metal binding reactions, and if equilibrium constants and site concentrations for other important metal adsorption and complexation reactions are known, the distribution of metals in realistic geologic systems can be calculated relatively easily.

\section{ACKNOWLEDGMENTS}

Research funding was provided by the National Science Foundation through grants EAR02-07169 and EAR02-21966. D.B. was partially supported through a University of Notre Dame Arthur J. Schmitt Presidential Fellowship. Thanks to Johnson Haas, Vern Phoenix, Jacqueline Claessens, Raul Martinez, David Ams, and Nathan Yee for providing electronic versions of their titration data for inclusion in this study. Vernon Phoenix, David Wesolowski, and an anonymous reviewer provided insightful reviews of the manuscript and significantly improved its presentation.

\section{REFERENCES}

Almeida, M. A., Cunha, M. A., and Alcantra, F., 2001, Factors influencing bacterial production in a shallow estuarine system: Microbial Ecology, v. 42, p. 416-426.

Ams, D., ms, 2004, Experimental studies of bacterial interactions with aqueous heavy metal cations and mineral surfaces: Ph.D. thesis, University of Notre Dame, Notre Dame, 108 p.

Beveridge, T. J., 1989, Role of cellular design in bacterial metal accumulation and mineralization: Annual Reviews in Microbiology, v. 43, p. 147-171.

Beveridge, T. J., and Fyfe, W. S., 1985, Metal fixation by bacterial-cell walls: Canadian Journal of Earth Science, v. 22, p. 1893-1898. 
Beveridge, T. J., and Murray, R. G. E., 1980, Sites of metal deposition in the cell wall of Bacillus subtilis: Journal of Bacteriology, v. 141, p. 876-887.

Borrok, D., and Fein, J. B., 2004, Distribution of protons and Cd between bacterial surfaces and dissolved humic substances determined through chemical equilibrium modeling: Geochimica et Cosmochimica Acta, v. 68, p. 3043-3053.

2005, The impact of ionic strength on the adsorption of protons, $\mathrm{Pb}, \mathrm{Cd}$, and Sr onto the surfaces of Gram negative bacteria: Testing non-electrostatic, diffuse, and triple layer models: Journal of Colloid and Interface Science, v. 286, p. 110-126.

Borrok, D., Fein, J. B., and Kulpa, C. F., 2004a, Proton and Cd adsorption onto natural bacterial consortia: testing universal adsorption behavior: Geochimica et Cosmochimica Acta, v. 68, p. 3231-3238.

Borrok, D., Fein, J. B., Tischler, M., O'Loughlin, E., Meyer, H., Liss M., and Kemner, K.M., 2004b, The Effect of Acidic Solutions and Growth Conditions on the Adsorptive Properties of Bacterial Surfaces: Chemical Geology, v. 209, p. 107-119.

Borrok, D., Fein, J. B., and Kulpa, C. F., 2004c, Cd and proton adsorption onto bacterial consortia grown from industrial wastes and contaminated geologic Settings: Environmental Science and Technology, v. 38 , p. $5656-5664$

Borrok, D., Borrok, M. J., Fein, J. B., and Kiessling, L. L., 2005, Link between Chemotactic Response to $\mathrm{Ni}^{2}$ and its Adsorption onto the Escherichia coli Cell Surface: Environmental Science and Technology, v. 39, p. 5227-5233, DOI: 10.1021/es0482381.

Boyanov, M. I., Kelly, S. D., Kemner, K. M., Bunker, B. A., Fein, J. B., and Fowle, D. A., 2002, Adsorption of cadmium to B. subtilis bacterial cell walls - a pH-dependent XAFS spectroscopy study: Geochimica et Cosmochimica Acta, v. 67, p 3299-3311.

Claessens, J., Behrends, T., and Van Cappellen, P., 2004, What do acid-base titrations of live bacteria tell us? A preliminary assessment: Aquatic Sciences, v. 66, p. 19-26.

Cox, J. S., Smith, D. S., Warren, L. A., and Ferris, F. G., 1999, Characterizing heterogeneous bacterial surface functional groups using discrete affinity spectra for proton binding: Environmental Science and Technology, v. 33, p. 4514-4521.

Daughney, C. J., and Fein, J. B., 1998, The effect of ionic strength on the adsorption $\mathrm{of}^{+}, \mathrm{Cd}^{2+}, \mathrm{Pb}^{2+}$, and $\mathrm{Cu}^{2+}$ by Bacillus subtilis and Bacillus licheniformis: a surface complexation model: Journal of Colloid and Interface Science, v. 198, p. 53-77.

Daughney, C. J., Fein, J. B., and Yee, N., 1998, A comparison of the thermodynamics of metal adsorption onto two common bacteria: Chemical Geology, v. 144, p. 161-176.

Daughney, C. J., Fowle, D. A., and Fortin, D., 2001, The effect of growth phase on proton and metal adsorption by Bacillus subtilis: Geochimica et Cosmochimica Acta, v. 65, p. 1025-1035.

Esposito, A., Pagnanelli, F., Lodi, A., Solisio, C., and Veglio, F., 2001, Biosorption of heavy metals by Sphaerotilus natans: an equilibrium study at different $\mathrm{pH}$ and biomass concentrations: Hydrometallurgy, v. 60 , p. $129-141$.

Fein, J. B., and Delea, D. E., 1999, Experimental study of the effect of EDTA on Cd adsorption by Bacillus subtilis: a test of the chemical equilibrium approach: Chemical Geology, v. 161, p. 375-383.

Fein, J. B., Daughney, C. J., Yee, N., and Davis, T. A., 1997, A chemical equilibrium model for metal adsorption onto bacterial surfaces: Geochimica et Cosmochimica Acta, v. 61, p. 3319-3328.

Fein, J. B., Boily, J. F., Yee, N., Gorman-Lewis, D., and Turner, B., 2005, Potentiometric titrations of Bacillus subtilis cells and a comparison of modeling approaches: Geochimica et Cosmochimica Acta, v. 69, p. 1123-1132.

Fisher, M. M., Graham, J. M., and Graham, L. E., 1998, Bacterial abundance and activity across sites within two Northern Wisconsin Sphagnum bogs: Microbial Ecology, v. 36, p. 259-269.

Haas, J. R., 2001, Thermodynamics of U(VI) sorption onto Shewanella putrefaciens: Chemical Geology, v. 180, p. 33-54.

2004, Effects of cultivation conditions on acid-base titration properties of Shewanella putrefaciens: Chemical Geology, v. 209, p. 67-81.

Haveman, S. A., Pedersen, K., and Ruotsalainen, P., 1999, Distribution and metabolic diversity of microorganisms in deep igneous rock aquifers of Finland: Geomicrobiology Journal, v. 16, p. 277-294.

He, L. M., and Tebo, B. M., 1998, Surface charge properties of and Cu(II) adsorption by spores of the marine Bacillus sp. Strain SG-1: Applied and Environmental Microbiology, v. 64, p. 1123-1129.

Hennig, C., Panak, P. J., Reich, T., Robberg, A., Raff, J., Selenska-Pobell, S., Matz, W., Bucher, J. J., Bernhard, G., and Nitsche, H., 2001, EXAFS investigation of uranium(VI) complexes formed at Bacillus cereus and Bacillus sphaericus surfaces: Radiochimica Acta, v. 89, p. 625-631.

Jiang, W., Saxena, A., Song, B., Ward, B., Beveridge, T. J., and Myneni, S. C. B., 2004, Elucidation of functional groups on Gram-positive and Gram-negative bacterial surfaces using infrared spectroscopy: Langmuir, v. 20, p. 11433-11442.

Kelly, S. D., Kemner, K. M., Fein, J. B., Fowle, D. A., Boyanov, M. I., Bunker, B. A., and Yee, N., 2002, X-ray absorption fine structure determination of pH-dependent U-bacterial cell wall interactions: Geochimica et Cosmochimica Acta, v. 66, p. 3855-3871.

Kulczycki, E., Ferris F. G., and Fortin D., 2002, Impact of cell wall structure on the behavior of bacterial cells as sorbents of cadmium and lead: Geomicrobiology Journal, v. 19, p. 553-565.

Marinsky, J. A., and Ephraim, J., 1986, A unified physicochemical description of the protonation and metal ion complexation equilibria of natural organic acids (humic and fulvic acids). 1. analysis of the influence of polyelectrolyte properties on protonation equilibria in ionic media: fundamental concepts: Environmental Science and Technology, v. 20, p. 349-354.

Martinez, R. E., Smith, D. S., Kulczycki, E., and Ferris, F. G., 2002, Determination of intrinsic bacterial surface acidity constants using a Donnan shell model and a continuous pKa distribution method: Journal of Colloid and Interface Science, v. 253, p. 130-139. 
Martino, D. P., Grossman, E. L., Ulrich, G. A., Burger, K. C., Schlichenmeyer, J. L., Suflita, J. M., and Ammerman, J. W., 1998, Microbial abundance and activity in a low-conductivity aquifer system in east-central Texas: Microbial Ecology, v. 35, p. 224-234.

Milne, C. J., Kinniburgh, D. G., and Tipping, E., 2001, Generic NICA-Donnan model parameters for proton binding by humic substances: Environmental Science and Technology, v. 35, p. 2049-2059.

Ngwenya, B. T., Sutherland, I. W., and Kennedy, L., 2003, Comparison of the acid-base behavior and metal adsorption characteristics of a Gram-negative bacterium with other strains: Applied Geochemistry, v. 18, p. 527-538.

Panak, P. J., Knopp, R., Booth, C. H., and Nitsche, H., 2002, Spectroscopic studies on the interaction of U(VI) with Bacillus sphaericus: Radiochimica Acta, v. 90, p. 779-783.

Phoenix, V. R., Martinez, R. E., Konhauser, K. O., and Ferris, F. G., 2002, Characterization and implications of the cell surface reactivity of Calothrix sp. strain KC97: Applied and Environmental Microbiology, v. 68, p. $4827-4834$.

Plette, C. C., Benedetti, M. F., Van Riemsdijk, W. H., and Van der Wal, A., 1995, pH dependent charging behavior of isolated cell walls of a Gram-positive soil bacterium: Journal of Colloid and Interface Science, v. 173, p. 354-363.

Small, T. D., Warren, L. A., Roden, E. E., and Ferris, F. G., 1999, Sorption of strontium by bacteria, Fe(III) oxide, and bacteria-Fe(III) oxide composites: Environmental Science and Technology, v. 33, p. 44654470.

Sokolov, I., Smith, D. S., Henderson, G. S., Gorby, Y. A., and Ferris, F. G., 2001, Cell surface electrochemical heterogeneity of the Fe(III)-reducing bacteria Shewanella putrefaciens: Environmental Science and Technology, v. 35, p. 341-347.

Tornabene, T. G., and Edwards, H. W., 1972. Microbial uptake of lead: Science, v. 176, p. 1334-1335.

Tortell, P. D., Maldonado, M. T., Granger, J., and Price, N. M., 1999, Marine bacteria and biogeochemical cycling of iron in the oceans: FEMS Microbiology and Ecology, v. 29, p. 1-11.

Turner, B. F., 2004, ProtoFit Version 1.0, a program for determining surface speciation constants from titration data: User's manual: http://protofit.sourceforge.net/

van der Wal, A., Norde, W., Zehnder, A. J. B., and Lyklema, J., 1997, Determination of the total charge in the cell walls of Gram-positive bacteria: Colloids and Surfaces B: Biointerfaces, v. 9, p. 81-100.

Wallberg, M., Brynhildsen, L., and Allard, B., 1991, Metal binding properties of Klebsiella oxytoca: Water, Air, and Soil Pollution, v. 57-58, p. 579-587.

Warren, L. A., and Ferris, F. G., 1998, Continuum between sorption and precipitation of Fe (III) on microbial surfaces: Environmental Science and Technology, v. 32, p. 2331-2337.

Westall, J. C., 1982, FITEQL, a computer program for determination for chemical equilibrium constants from experimental data: Version 2.0, Report 82-02, Department of Chemistry, Oregon State University, Corvallis, Oregon, USA.

Westall, J. C., Jones, J. D., Turner, G. D., and Zachara, J. M., 1995, Models for association of metal ions with heterogeneous environmental sorbents. 1. complexation of $\mathrm{Co}$ (II) by leonardite humic acid as a function of $\mathrm{pH}$ and $\mathrm{NaClO}_{4}$ concentration: Environmental Science and Technology, v. 24, p. 951-960.

Wightman, P. G., Fein, J. B., Wesolowski, D. J., Phelps, T. J., Bénézeth P., and Palmer, D. A., 2001, Measurement of bacterial surface protonation constants for two species at elevated temperatures: Geochimica et Cosmochimica Acta, v. 65, p. 3657-3669.

Yee, N., and Fein, J. B., 2001, Cd adsorption onto bacterial surfaces: A universal adsorption edge?: Geochimica et Cosmochimica Acta, v. 66, p. 2037-2042.

2003, Quantifying metal adsorption onto bacteria mixtures: a test and application of the surface complexation model: Geomicrobiology Journal, v. 20, p. 43-60.

Yee, N., Fowle, D. A., and Ferris, F. G., 2004, A Donnan potential model for metal sorption onto Bacillus subtilis: Geochimica et Cosmochimica Acta, v. 68, p. 3657-3664.

Zweifel, U. L., and Hagstrom A., 1995, Total counts of marine bacteria include a large fraction of non-nucleoid-containing bacteria (ghosts): Applied and Environmental Microbiology, v. 61, p. 21802185 . 